American Journal of Remote Sensing
2020; $8(1): 1-19$
http://www.sciencepublishinggroup.com/j/ajrs
doi: 10.11648 /j.ajrs.20200801.11
ISSN: 2328 -5788 (Print); ISSN: $2328-580 \mathrm{X}$ (Online)

\title{
Land Use and Land Cover Change Within and Around the Greater Serengeti Ecosystem, Tanzania
}

\author{
Hamza Khalid Kija ${ }^{1,2, *}$, Joseph Ochieng Ogutu ${ }^{3}$, Lazaro Johana Mangewa ${ }^{1}$, John Bukombe ${ }^{2}$, \\ Francesca Verones ${ }^{4}$, Bente Jessen Graae, Jafari Ramadhani Kideghesho ${ }^{6}$, \\ Mohammed Yahya Said ${ }^{5,7}$, Emmanuel Fred Nzunda $^{8}$ \\ ${ }^{1}$ Department of Wildlife Management, College of Forestry, Wildlife and Tourism, Sokoine University of Agriculture, Morogoro, Tanzania \\ ${ }^{2}$ Conservation Information and Monitoring Unit (CIMU), Tanzania Wildlife Research Institute (TAWIRI), Arusha, Tanzania \\ ${ }^{3}$ Biostatistics Unit, Institute of Crop Science, University of Hohenheim, Stuttgart, Germany \\ ${ }^{4}$ Department of Energy and Process Engineering, Norwegian University of Science and Technology, Trondheim, Norway \\ ${ }^{5}$ Department of Biology, Norwegian University of Science and Technology, Trondheim, Norway \\ ${ }^{6}$ College of African Wildlife Management (CAWM), Moshi, Tanzania \\ ${ }^{7}$ Institute for Climate Change and Adaptation, University of Nairobi, Nairobi, Kenya \\ ${ }^{8}$ Department of Forest Resources Assessment and Management, College of Forestry, Wildlife and Tourism, Sokoine University of Agriculture, \\ Morogoro, Tanzania
}

\section{Email address:}

hamza.kija@tawiri.or.tz(H. K. Kija),jogutu2007@gmail.com (J. O. Ogutu), ljohannah@yahoo.co.uk (L. J. Mangewa), bukombe2017@gmail.com (J. Bukombe), francesca.verones@ntnu.no (F. Verones), bente.j.graae@ntnu.no (B. J. Graae), kideghesho@yahoo.com (J. R. Kideghesho), msaid362@gmail.com (M. Y. Said), nzunda@sua.ac.tz (E. F. Nzunda)

* Corresponding author

\section{To cite this article:}

Hamza Khalid Kija, Joseph Ochieng Ogutu, Lazaro Johana Mangewa, John Bukombe, Francesca Verones, Bente Jessen Graae, Jafari Ramadhani Kideghesho, Mohammed Yahya Said, Emmanuel Fred Nzunda. Land Use and Land Cover Change Within and Around the Greater Serengeti Ecosystem, Tanzania. American Journal of Remote Sensing. Vol. 8, No. 1, 2020, pp. 1-19. doi: 10.11648/j.ajrs.20200801.11

Received: March 3, 2020; Accepted: March 20, 2020; Published: April 29, 2020

\begin{abstract}
Land use and land cover (LULC) changes can pose profound impacts on wildlife habitats, abundance and distribution and on human-dominated landscapes. We investigated LULC changes in the Greater Serengeti ecosystem, Tanzania, for a period of 41 years from 1975 to 2015. Specifically, we mapped LULC types for 1975, 1995 and 2015 and assessed the corresponding changes during 1975-1995, 1995-2015 and 1975-2015. We used the random forest classification algorithm to classify Multispectral Scanner (MSS), Thematic Mapper (TM), Enhanced Thematic Mapper Plus (+ETM) and Operational Land Imager (OLI) into eight main classes. We obtained accuracies of $88.4 \%, 90.6 \%$ and $93.4 \%$ with Kappa Indices of Agreement (KIA) of $0.86,0.87$ and 0.91 for 1975, 1995 and 2015, respectively. Grassland, shrubland and woodland were the major LULC types throughout 1975-2015 with percentage coverages of $50.6 \%, 23.7 \%$ and $20.9 \%$ for $1975 ; 54.2 \%, 23.5 \%$ and $15.9 \%$ for 1995 ; and $57.0 \%, 23.8 \%$ and $8.9 \%$ for 2015, respectively. Overall, woodland cover (-11.1\%) was converted to most of the other cover types during 1975-2015. The loss of woodland cover is due to increasing human population size, agriculture, settlements and policy changes fires and elephant browsing. Effective conservation policies and regulation of socio-economic activities in the ecosystem and its buffer area are essential to ameliorate declining vegetation cover, especially along the protected areas boundaries.
\end{abstract}

Keywords: Land Use and Cover Change, Land Cover Transformation, Random Forest Classification, GIS and Remote Sensing, Serengeti Ecosystem, Wildlife Habitats

\section{Introduction}

Land use and land cover (LULC) are important components of natural ecosystems. Land cover provides habitats for wildlife, while land use shapes the land cover, and consequently, alters the habitat types and wildlife species [1]. 
Anthropogenic activities are increasingly altering habitats and their ecosystem services especially in terrestrial ecosystems [2]. LULC changes can exert profound impacts on the structure and function of terrestrial ecosystems. Notably, complex interactions between land use and land cover in human-dominated landscapes interfere with biotic and abiotic factors and processes, with often adverse consequences for wildlife habitats, abundance and species diversity [3]. LULC changes, including in wildlife habitats, are accelerating globally and escalating habitat degradation and declines in abundance and distributional ranges of species [4, 5].

The Serengeti ecosystem in Tanzania is an exemplar of ecosystems experiencing intense and mounting pressures due to anthropogenic-induced land use and land cover changes along its borders [6]. As a result, the ecosystem has undergone significant land use and land cover changes particularly over the 41 years spanning from 1975 to 2015 . This is disturbing since this ecosystem is one of the earth's remaining tropical biodiversity hotspots and hosts hosting some of the largest remaining free-ranging ungulate populations [7]. Notably, substantial land cover has been converted to small-scale agriculture near the boundary of the Serengeti whereas increasing livestock numbers are regularly encroaching into the park in search of pasture $[6,8]$. Moreover, expanding human and livestock population growth, settlements and agriculture are intensifying the pressure falling on wildlife habitats and therefore, threatening wildlife populations and shrinking their distribution in the ecosystem [8, 9]. LULC changes not only contract the distribution but also degrade the quality of wildlife habitats, heightening their sensitivity to climatic and other perturbations [9-11].

Despite the rapid and striking LULC changes, relatively few studies $[12,13]$ have examined these changes within and around the Serengeti ecosystem. Furthermore, previous studies of LULC changes in wildlife habitats in the Serengeti are fragmented and have focused either only on specific habitat types (e.g., grasslands or woodlands), habitats proximate to human-dominated landscapes [14-17], or only on predicting spatial distribution and habitat suitability for particular wildlife species inside the protected areas [18-20]. It is therefore important to quantify the extent and magnitude of LULC changes within and around ecosystems of great ecological and economic importance, such as the Serengeti, as a basis for forecasting their likely long-term trajectories and potential consequences for wildlife habitats and populations. Importantly, a better understanding of spatial and temporal land use and land cover dynamics is imperative for effective spatial land use planning and policies, biodiversity conservation and management and human wellbeing.

Accordingly, our aim was to investigate long-term LULC changes in the Serengeti ecosystem and its surrounding buffer area for a period of 41 years from 1975 to 2015. Specifically, we use multi-spectral, remotely sensed data to $(i)$ map land use and land cover during 1975, 1995 and 2015 and (ii) assess LULC changes during 1975-1995, 1995-2015 and 1975-2015.

The three study time slices (1975-1995, 1995-2015) were selected to capture effects of major perturbations in the ecosystem. The first slice (1975-1995) was preceded by a national resettlement program in Tanzania in 1974 in which people were forced to live in village clusters (villagization). This caused a sudden increase in human population densities in the resettlement areas $[8,21,22]$. The villagization program changed LULC where it was implemented [21]. In addition, changes introduced in agricultural policies between 1974 and 1983 compounded the impacts of the villagization program on the environment. The second study slice (1995-2015) coincided with continuation of the policies that promoted expansion of agricultural production in Tanzania, thus driving further LULC changes [23, 24]. The broad study window (1975-2015) was considered to establish the overall LULC changes in the ecosystem and its surrounding buffer area.

\section{Materials and Methods}

\subsection{Description of the Study Site}

The study was conducted in the Serengeti ecosystem in northern Tanzania $\left(1^{\circ} 20^{\prime} 50^{\prime \prime}\right.$ to $3^{\circ} 50^{\prime} 05^{\prime \prime} \mathrm{S} ; 33^{\circ} 08^{\prime}$ to $32^{\prime \prime}$ $\left.36^{\circ} 42^{\prime} 38^{\prime \prime} \mathrm{E}\right)$. The ecosystem is an outstanding biodiversity hotspot and is home to the SNP and the Ngorongoro Conservation Area both of which are Biosphere Reserves and World Heritage Sites [17]. The ecosystem covers about 33,150 $\mathrm{km}^{2}$ and comprises nine protected areas (under different conservation administrations), including a national park, a multiple land use area, game reserves, game controlled areas and wildlife management areas (Figure 1). The study area also included an unprotected buffer area covering some 23, 487 $\mathrm{km}^{2}$ around the core study ecosystem. The total study area thus covered some $56,592 \mathrm{~km}^{2}$. The degree of protected and permitted land use types vary widely within the ecosystem and its buffer area, with direct implications for LULC types and changes. The conservation status of the protected areas against human activities is the highest for the Serengeti National Park SNP, followed in decreasing order, by the Ngorongoro Conservation Area (NCA), Game Reserves (GRs), Loliondo Game Controlled Area (LGCAs), Wildlife Management Areas (WMAs) and the buffer area (BF). Human habitation is prohibited in the national park and game reserves. Only conservation and photographic tourism are allowed in the national park. Licensed hunting is allowed in the Game Reserves, Game Controlled Areas and Wildlife Management Areas. The NCA is a multiple land use area allowing human settlement and pastoralism. Farming, which was allowed in 1992 through the Prime Minister Decree was prohibited in the NCA in 2009. Human settlement and socio-economic activities were allowed with minimal restrictions in the Game Controlled Areas until the Wildlife Act No. 5, which outlawed these activities, was promulgated in 2009.

Rainfall in the ecosystem is strongly bimodal, with the wet season spanning from November to May and the dry season commencing from June to October. The wet season consists of the short (November-December) and long (March-May) rains, separated by a relatively dry period in January-February [16]. Rainfall varies widely in space and time and increases from an 
annual average of $500 \mathrm{~mm}$ in the southeast to $1150 \mathrm{~mm}$ in the northwest and from $500 \mathrm{~mm}$ in the East to $950 \mathrm{~mm}$ in the west $[25,26]$. Part of the spatial variation in rainfall is due to topographical gradients in the ecosystem. Temperatures are generally warm year-round and averages $27^{\circ} \mathrm{C}$ [25].

The ecosystem supports a mixture of diverse vegetation types, ranging from grassland plains in the south-eastern and western regions of Serengeti and northern Ngorongoro [27], to north of Grumeti river and woodlands in Maswa and a mosaic of woodlands and closed gallery forests along major rivers in
Ikorongo-Grumeti Game Reserve [16, 28]. Other vegetation types include riverine forests, swamps, grasslands, woodlands and open-woodlands [27], with woodlands, covering $60 \%$ of the ecosystem, being the dominant vegetation type [28]. It is home to abundant herds of diverse ungulate species, including the migratory wildebeest (Connochaetes taurinus), zebra (Equus quagga burchellii), Thomson's gazelle (Gazella thomsoni), and other species, such as buffalo (Syncerus caffer) and elephants (Loxodonta africana) [7, 29].

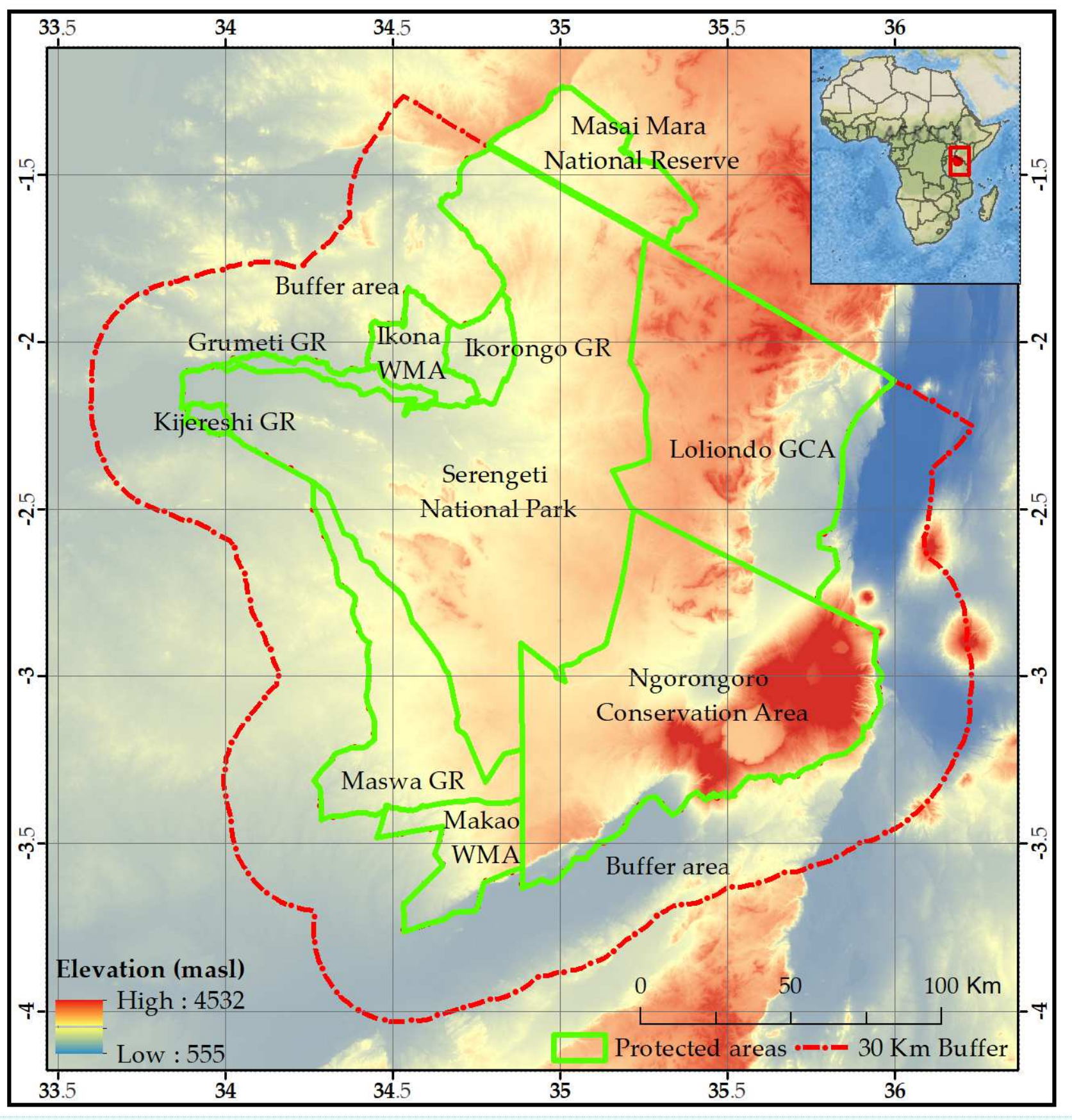

Figure 1. Map of the study area showing the protected and buffer areas. 


\subsection{Image Acquisition and Pre-processing}

Landsat Multispectral Scanner (MSS), Thematic Mapper (TM) and Landsat-8 (Operational Land Imager) time series images for the years 1975,1995 and 2015 that correspond to paths 168, 169 and 170 and rows 61,62 and 63 of the Landsat Worldwide Reference System (WRS) were downloaded from the Earth Explorer (https://earthexplorer.usgs.gov/) web platform. The effect of seasonal differences in vegetation phenology between study windows was minimized by downloading image scenes captured on similar satellite overpass times or seasons (Dry periods spanning January-February, July-August and October-November). Dry season images have relatively lower cloud cover than wet season images. Details of the Landsat images used are summarized in Table 1.

Table 1. Details of the Landsat images used for LULC mapping.

\begin{tabular}{lllll}
\hline Image date & Image type & Resolution & Path and Row & Data Source \\
\hline \multirow{3}{*}{1975} & Landsat MSS & $57 \times 57 \mathrm{~m}$ & $168 / 61-62$ & United States Geological Survey \\
& Landsat MSS & $57 \times 57 \mathrm{~m}$ & $169 / 61-63$ & United States Geological Survey \\
& Landsat MSS & $57 \times 57 \mathrm{~m}$ & $170 / 61-62$ & United States Geological Survey \\
1995 & Landsat TM & $30 \times 30 \mathrm{~m}$ & $168 / 61-62$ & United States Geological Survey \\
& Landsat TM & $30 \times 30 \mathrm{~m}$ & $169 / 61-63$ & United States Geological Survey \\
& Landsat TM & $30 \times 30 \mathrm{~m}$ & $170 / 61-62$ & United States Geological Survey \\
2015 & Landsat (OLI) & $30 \times 30 \mathrm{~m}$ & $168 / 61-62$ & United States Geological Survey \\
& Landsat (OLI) & $30 \times 30 \mathrm{~m}$ & $169 / 61-63$ & United States Geological Survey \\
& Landsat (OLI) & $30 \times 30 \mathrm{~m}$ & $170 / 61-62$ & United States Geological Survey \\
\hline
\end{tabular}

Prior to analysis, images were corrected for geometric and radiometric effects [30-32]. Such pre-processing is useful to remove false indication of objects and facilitates comparison of multi-temporal images and field-based data [33, 34], and ensures that the corrected images are of sufficiently high quality for analysis [31]. Image and/or sensor differences within and between scenes were normalized by converting the brightness values of each pixel (Digital Number (DN) to actual reflectance (Top of Atmosphere Reflectance (TOA)), in order to obtain the actual ground reflectance [35]. Topographic normalization is a crucial part of atmospheric correction [36-38] as it enhances representation of the original image, hence improving spectral signatures, classification and overall accuracy $[35,39]$.

A Digital Elevation Model (DEM), covering the entire study area at a spatial resolution of $30 \mathrm{~m}$, derived from the Shuttle Radar Topography Mission (SRTM) was used to correct images that are acquired from undulating, mountainous or hilly (topographic effects) and/or rugged terrain lands [40]. Topographic correction is an important pre-processing stage as it improves accuracy of thematic maps [41]. Geometric correction was not performed as Landsat Level-1 products are terrain-corrected [32]. Atmospheric effects on the images were corrected through haze removal and masking clouds in the scenes using the Atmospheric Correction Tool [42].

\subsection{Cloud Removal}

Satellite images tend to have clouds. It was almost impossible to get cloud-free image scenes that covered the entire study area. Therefore, sections of a scene with clouds were first removed and the resulting gaps filled with corresponding sections of cloud-free images for the same scene taken closely in time, or in the same season and the gap-filled using the Smart GeoFill tool [42].

\subsection{Image Mosaicking and Sub Setting}

The geometric and radiometric corrected scenes were seamlessly stitched in PCI Geomatica [42] to obtain one image covering the entire ecosystem. Image scenes were then clipped to individual strata (the various protected areas plus the buffer area) for minimizing the spread of classes to other areas that do not belong to it, and to speed up the classification process.

\subsection{Sampling Design}

i. Sample Size and Distribution of Samples

The study area was stratified into 10 strata, each corresponding to one of the nine protected areas and the surrounding $30-\mathrm{km}$ wide unprotected buffer area on the Tanzanian side of the Greater Serengeti-Mara ecosystem (Figure 1). LULC variability was high in each stratum, implying a high likelihood of having different classes for LULC Based on Congalton [43] and the principle of binomial distribution, a minimum of 75-100 validation samples per class are suggested for analysis. However, due to logistical and financial constraints, terrain features and legal prohibition of driving off-road within protected areas, approximately $30 \%$ of the required sample size was validated for a total of $n=1918$ sampling points.

Despite these constraints, the sample sizes for the collected test and validation data are higher than the minimum recommended sample size [43] and thus were considered sufficient for reliable classification. Samples were randomly allocated in proportion to the area of each LULC type represented in each stratum, using a pre-defined baseline map. However, for infrequent classes (water, wetland/swamps, and bareland), the estimated sample size was adjusted upwards by selecting additional samples using Google Earth and Bing images.

ii. Collection of Sample Points

The selected random samples were traced on the ground using hand-held Garmin CSX GPS. Sample points falling in inaccessible areas (due to terrain features or absence of roads), and restricted off-road access were replaced with samples from nearby pixels with similar reflectance or overlaid on high resolution Google Earth (https:/www.google.com/intl/de/earth/) 
and Bing (https://www.bing.com/maps) images and the corresponding object and/or LULC identified [44]. In order to minimize the likelihood of misclassifying the sampled LULC, spectral signatures for the selected sample points were inspected in scatter plots. Opportunistic observations made while travelling from one sampling point to another supplemented the training and testing data sets.

For historical images, the Herlocker (1976) and Reed [13] maps were used to obtain the training and testing sets for the 1975 and 1995 imageries, respectively. A minimum of 75-100 samples per category (Table 2) were extracted. Less covered class samples were supplemented by collecting additional manually extracted samples from the imageries using spectral characteristics.

\section{iii. Digitization and Selection of Training and Test Sets}

Multi-resolution segmentation was performed in E-Cognition [45] on each strata image to obtain polygons (area representing a land cover feature of regular, irregular, circular or elliptical shape) which reflects different ground objects based on image spectral characteristics, shape and tone Segmentation parameters were set as follows: scale $=1$, shape $=0.1$ and compactness $=0$. Field samples were overlaid on to the segmented image and corresponding polygons extracted.

The spatial join tool (ArcGIS 10.5) was used to overlay the LULC on to corresponding classes in the field samples (Table 2). Then, a research tool (random selection within subsets) in QGIS 3.10 was used to randomly partition the samples into training (50\%) and testing (50\%) sets for classification and accuracy assessment, respectively, based on the LULC categories.

iv. Signature separability

The training and test samples were evaluated for class spectral signature separability. This is the statistical measure of the distance between two object signatures that can be correctly assigned to proper LULC patterns that do not overlap with one another. Signature separability was tested in PCI Geomatica [42] using the Bhattacharyya distance (BD) using bands 3, 4 and 5. BD is a separation index, with values ranging from 0 to 2 , with 0 indicating total overlap and 2 indicating purely separable signatures. Two objects are separable if the separation distance between them is statistically significant and sufficient to produce a successful classification. Thus, to enhance classification, signatures with good separability $(1.9<\mathrm{x}<2.0)$ were retained, and the poorly separated signatures $(1.0<\mathrm{x}<1.9)$ were either merged or edited until a reasonable separability level was attained, where $\mathrm{x}$ is the separability distance between two samples.

v. Image Classification

Image classification was performed using the Random Forest (RF) coded script [46] that is run in the R software package. RF is a powerful machine learning classifier that is widely used in land-based remote sensing because it has a high classification accuracy, is more robust to noise than many other competing classifiers and is a non-parametric classifier $[47,48]$. Furthermore, it is able to impute missing values and rank variables in order of their importance, and allows reliable assessment of the predictive accuracy of classification [48, 49]. Shuttle Radar Topography Mission (SRTM) derivatives (Digital Elevation Model, Slope and Topographic Wetness Index) were combined with the spectral multi-temporal data to improve the classification and accuracies of the classified LULC maps [50, 51]. To increase precision and accuracy, images scenes that are part of different strata were first classified independently and then merged.

For each classification run, three outputs are produced, namely; the classImage, probImage and threshImage. The classImage, is an output of the classified image. The probImage that shows the probability of correct classification of the classImage layer. On the other hand, threshImage identifies classified pixels with inter-class confusion by highlighting pixels with a probability of correct classification that is lower than a user-specified threshold. Besides the three optional raster outputs, a point vector file, "Margin file", is file that reports assessment of the quality of sample data. Positive margin values represent correct classification, and vice versa, and provide a basis for removing poorly classified samples or relabeling sample data. Moreover, it helps to determine which classes need additional training signatures. Before the final RF classification, 2-3 runs were performed and the run with the best accuracy, i.e., above $85 \%$, selected as the final classification. Procedures for image pre-processing, processing and post-processing are summarized in Figure 2.

vi. Accuracy Assessment and Error Matrix

The agreement between the ground truthing data and the classified map (accuracy assessment) was assessed by an error matrix $[52,53]$ using the test dataset (50\% of the full sample). The error matrix (cross-tabulation) table for each thematic image was generated. Kappa Index of Agreement (KIA) that measures how well the classified map matches the reference data [54] was also computed.

In thematic classification, an overall accuracy of $\geq 85 \%$ is considered acceptable, provided the per-class accuracy is at least $70 \%$ [44]. Accuracy assessment is accompanied by KIA, a measure of how well the classified map matches the reference data. KIA values greater than 0.8 indicate perfect classification whereas values lying between 0.6 and 0.8 indicate good classification [55]. Therefore, the KIA values we obtained indicate acceptable classification [56, 57].

vii. Post-classification: Change Detection Analysis

A majority filter $(3 \times 3$ pixels $)$ as recommended [58] was applied to the thematic maps to eliminate the salt-and-pepper effects (Figure 2). Consequently, the smallest mappable unit (MU) for the classified map in the ecosystem was about 1 hectare. In order to identify the type, magnitude and spatial aspects of LULC changes between the images for 1975 versus 1995, 1995 versus 2015 and 1975 versus 2015, a post-classification change detection was performed in the Semi-Automatic Classification Plugin in QGIS software [59]. In order to enable multi-temporal comparison with the rest of the images, a Nearest Neighbor Sampling Algorithm (NNSA) was used to re-sample the MSS classified images to $30 \times 30 \mathrm{~m}$ pixel. Post-classification comparison or change detection was used to estimate the percentage change between two images. 


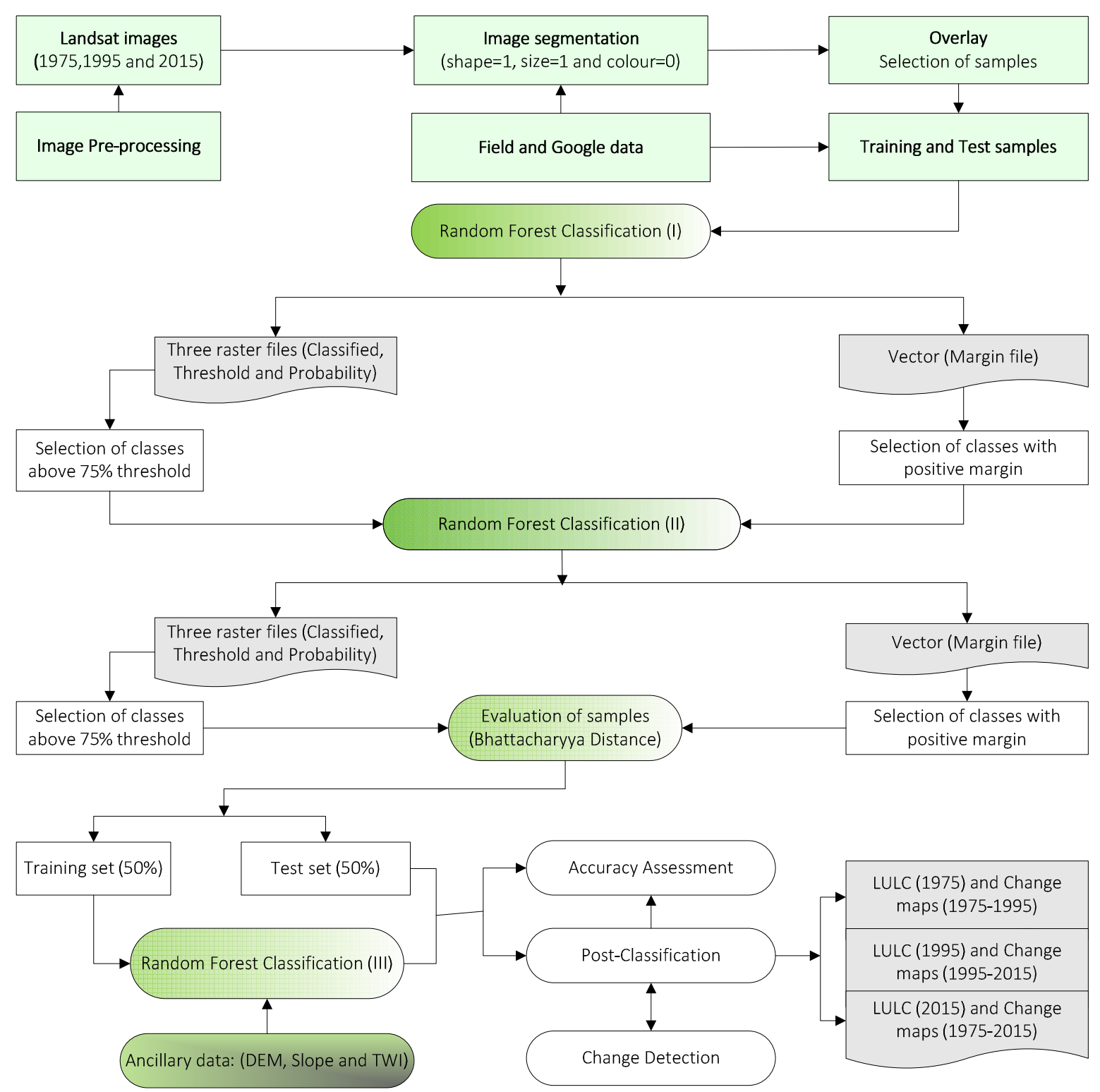

Figure 2. Flow chart for image classification.

Table 2. Description of LULC classes.

\begin{tabular}{ll}
\hline Land use and cover & Land use and cover class descriptions \\
\hline Bareland & Any area with vegetation cover between 0 and $2 \%$, and includes areas that are barren land, bare rocks and/or soil that are \\
exposed due to burning of trees and shifting cultivation \\
Cultivation & Consists of land parcels that are used for subsistence or commercial farming \\
Settlement & Areas that are designated as small towns, villages and roads \\
Water & Areas that are covered by water bodies, such as rivers, dams and lakes \\
Grassland & Areas with non-woody vegetation, comprised of short and tall grasses, used primarily for wildlife and livestock grazing. Rice \\
Shrubland & fields, plantations, and non-irrigated land are excluded from this class \\
Woodland & Woody vegetation, with multi-stem and height of 3-5 m \\
Wetland and Swamps & Areas with woody vegetation with a height between $6-15 \mathrm{~m}$ \\
\hline
\end{tabular}

Source: Modified from Tekle, K. and Hedlund, L. [60].

\section{Results}

\subsection{Land Use and Land Cover Types}

The spatial distributions of LULC types in the Serengeti ecosystem and its surrounding buffer area in 1975, 1995 and 2015 are illustrated in Figures 3-5, respectively. The overall accuracies of the classified maps were $88.4 \%, 90.6 \%$ and $93.4 \%$ and the corresponding Kappa Indices of Agreement were 0.86, 0.87 and 0.91 for 1975,1995 and 2015, respectively. The areal 
and percentage coverages of the individual LULC classes are summarized in Table 3.

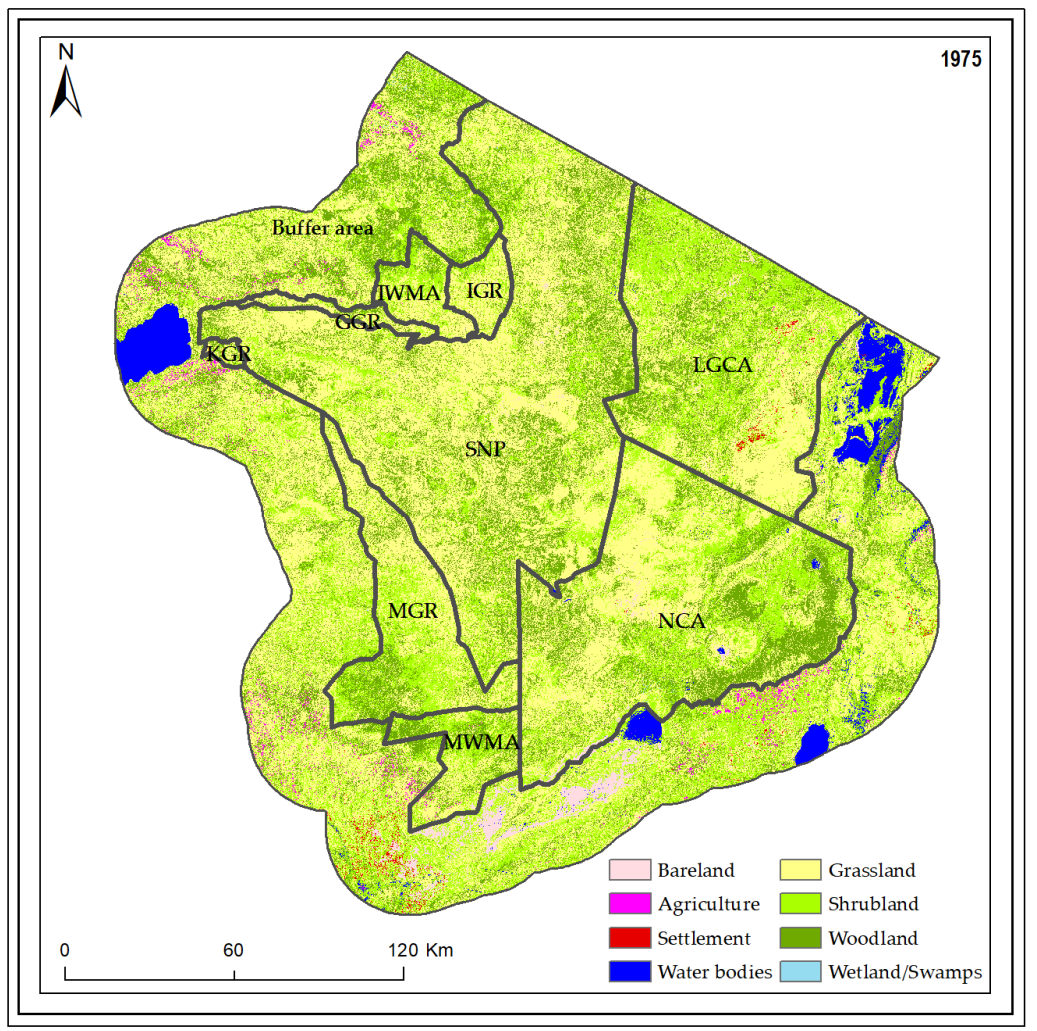

Figure 3. Distribution of LULC types in the Serengeti ecosystem and surrounding buffer zone in 1975.

Where: LGCA=Loliondo Game Controlled Area, MWMA=Makao Wildlife Management Area, IWMA=Ikona Wildlife Management Area, NCA=Ngorongoro Conservation Area, MGR=Maswa Game Reserve, IGR=Ikorongo Game Reserve, KGR=Kijereshi Game Reserve, GGR=Grumeti Game Reserve, $\mathrm{SNP}=$ Serengeti National Park.

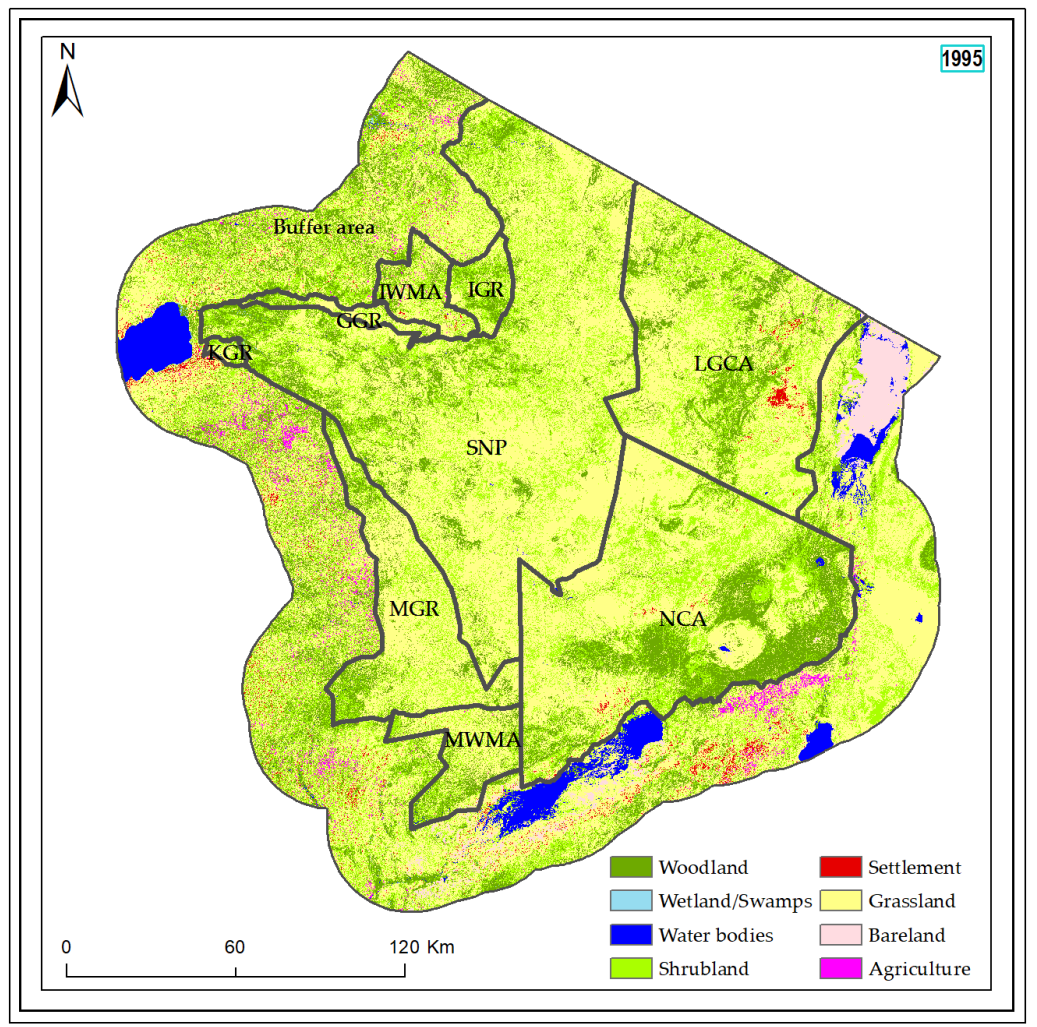

Figure 4. Distribution of LULC types in the Serengeti ecosystem and surrounding buffer zone in 1995. 


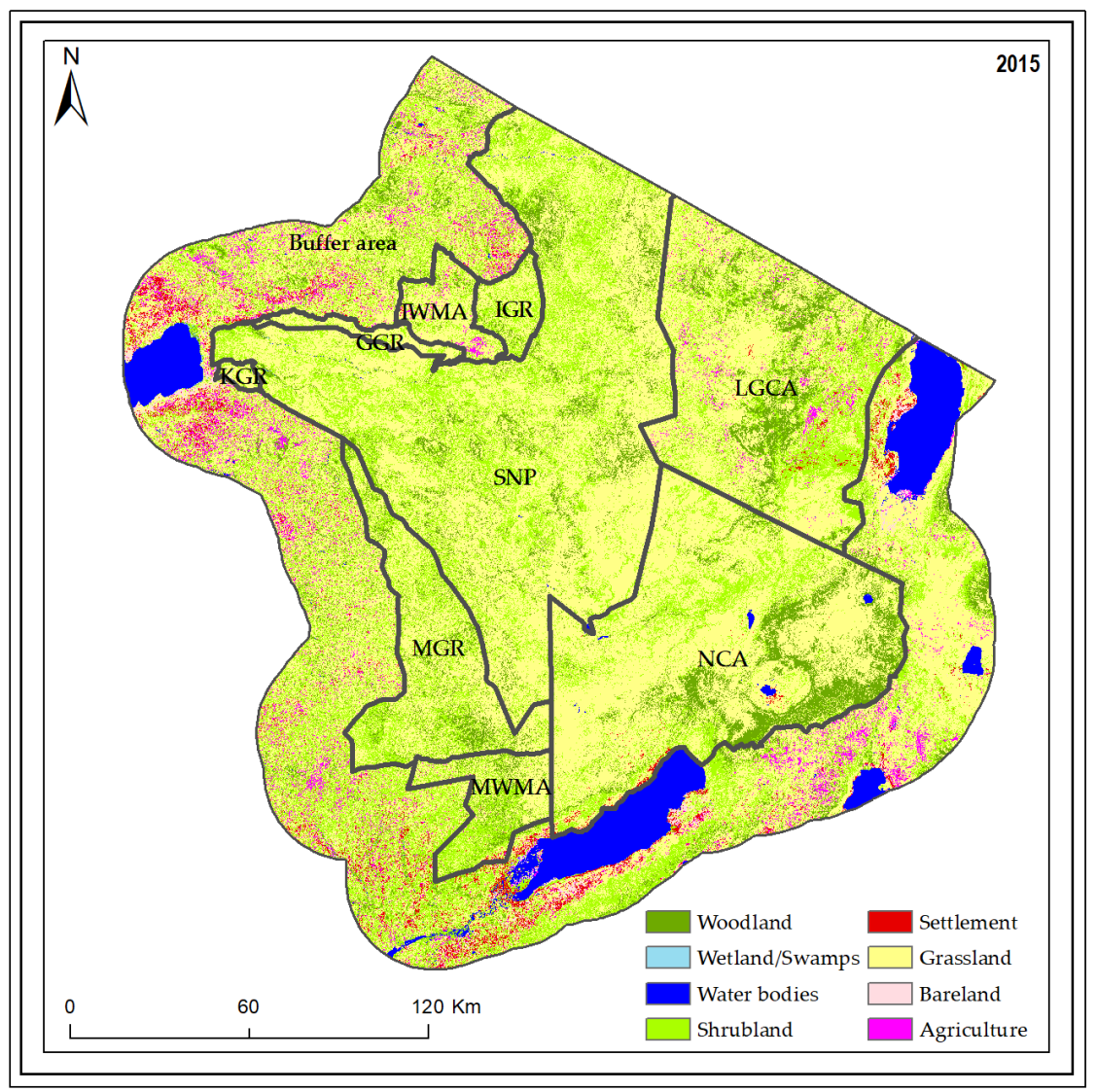

Figure 5. Distribution of LULC types in the GSE and surrounding buffer zone in 2015.

Across the entire ecosystem and its buffer area, grassland was the major land cover class, followed by shrubland and woodland whereas wetland/swamps, settlement, agriculture and bareland had relatively low coverages during 1975-2015 (Table 3).

Table 3. The areal and percentage coverages of LULC classes in the GSE and surrounding buffer area in 1975, 1995 and 2015.

\begin{tabular}{lllllll}
\hline \multirow{2}{*}{ LULC Class } & \multicolumn{7}{l}{ Area coverage $\mathbf{( k m}^{\mathbf{2}}$ ) } & \multicolumn{3}{l}{ Percentage (\%) } \\
\cline { 2 - 7 } & $\mathbf{1 9 7 5}$ & $\mathbf{1 9 9 5}$ & $\mathbf{2 0 1 5}$ & $\mathbf{1 9 7 5}$ & $\mathbf{1 9 9 5}$ & $\mathbf{2 0 1 5}$ \\
\hline Bareland & 781 & 1,003 & 371 & 1.38 & 1.77 & 0.65 \\
Agriculture & 381 & 643 & 1,789 & 0.67 & 1.14 & 3.16 \\
Settlement & 144 & 498 & 982 & 0.25 & 0.88 & 1.73 \\
Water & 1,403 & 1,456 & 2,664 & 2.48 & 2.57 & 4.71 \\
Grassland & 28,649 & 30,685 & 32,278 & 50.62 & 54.21 & 57.03 \\
Shrubland & 13,384 & 13,273 & 13,442 & 23.65 & 23.45 & 23.75 \\
Woodland & 11,812 & 9,005 & 5,046 & 20.87 & 15.91 & 8.92 \\
Wetland/Swamps & 37 & 28 & 18 & 0.06 & 0.05 & 0.03 \\
Total & 56,590 & 56,590 & 56,590 & 100 & 100 & 100 \\
\hline
\end{tabular}

Protected areas had higher proportions of grassland, shrubland and woodland coverages than the buffer area throughout 1975, 1995 and 2015. The buffer had high proportions of grassland, shrubland and woodland in 1975 and 1995 but was dominated by grassland and shrubland in 2015 . The other LULC classes had relatively low proportional coverages in both the protected and buffer areas in 1975, 1995 and 2015 (Figure 6).

Grassland was the most dominant land cover type in all the protected areas and the buffer area throughout 1975-2015. It had the highest proportional coverage in the buffer area followed by the SNP, NCA and the LGCA. Grassland coverage varied little in the buffer area but increased slightly in the NCA, LGCA and SNP during 1975-2015 (Figure 7). Shrubland coverage similarly varied little in the buffer area, decreased in the NCA and GCA but increased in the SNP during 1975-2015 (Figure 7). Woodland coverage decreased persistently and strikingly in the buffer area and all the protected areas from 1975 to 2015 (Figure 7). The coverages of water, agriculture and settlement expanded in the buffer area from 1975 to 2015 (Figure 7). 


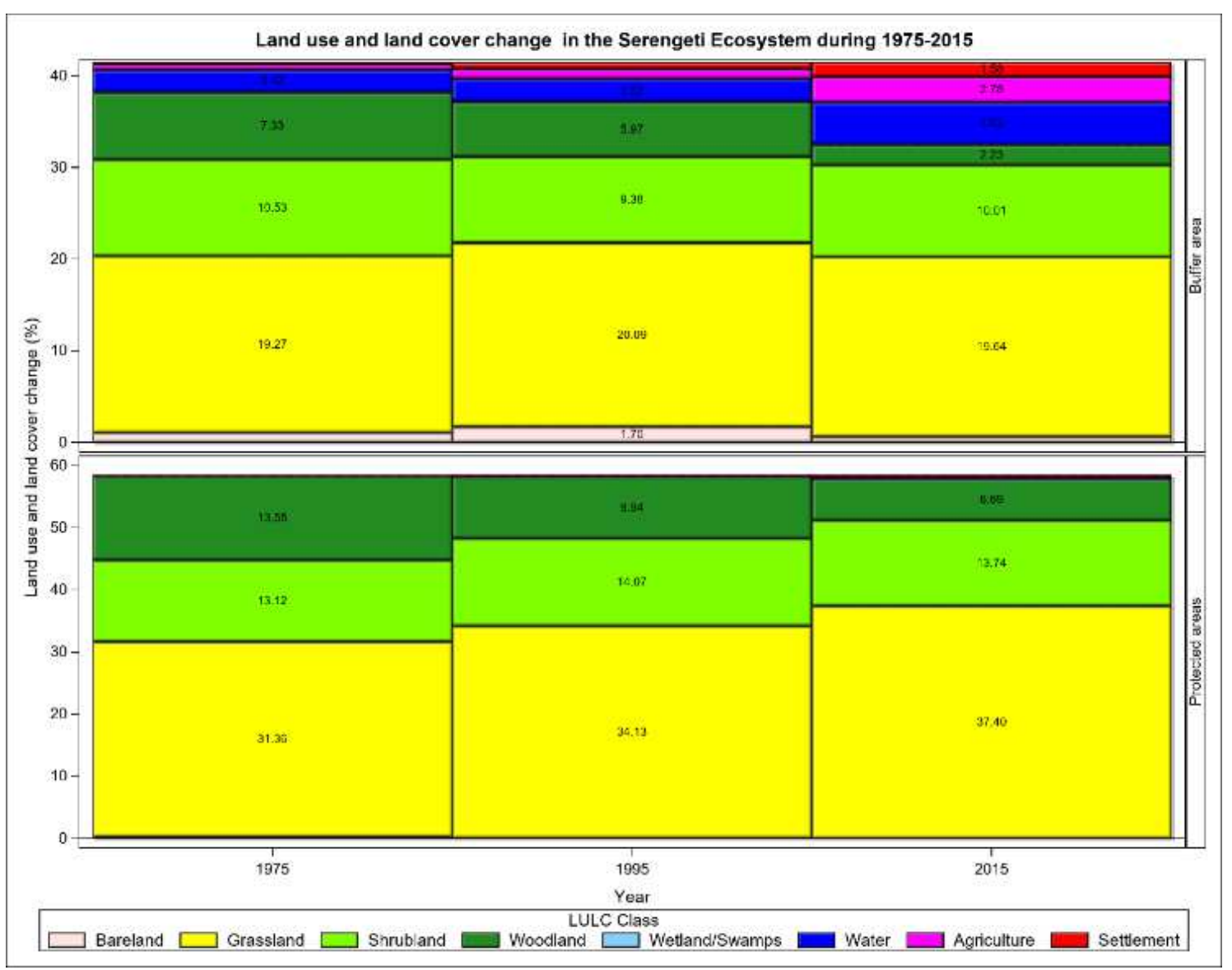

Figure 6. Percentage coverage of LULC classes in all the protected areas in the GSE and surrounding buffer area in 1975, 1995 and 2015.

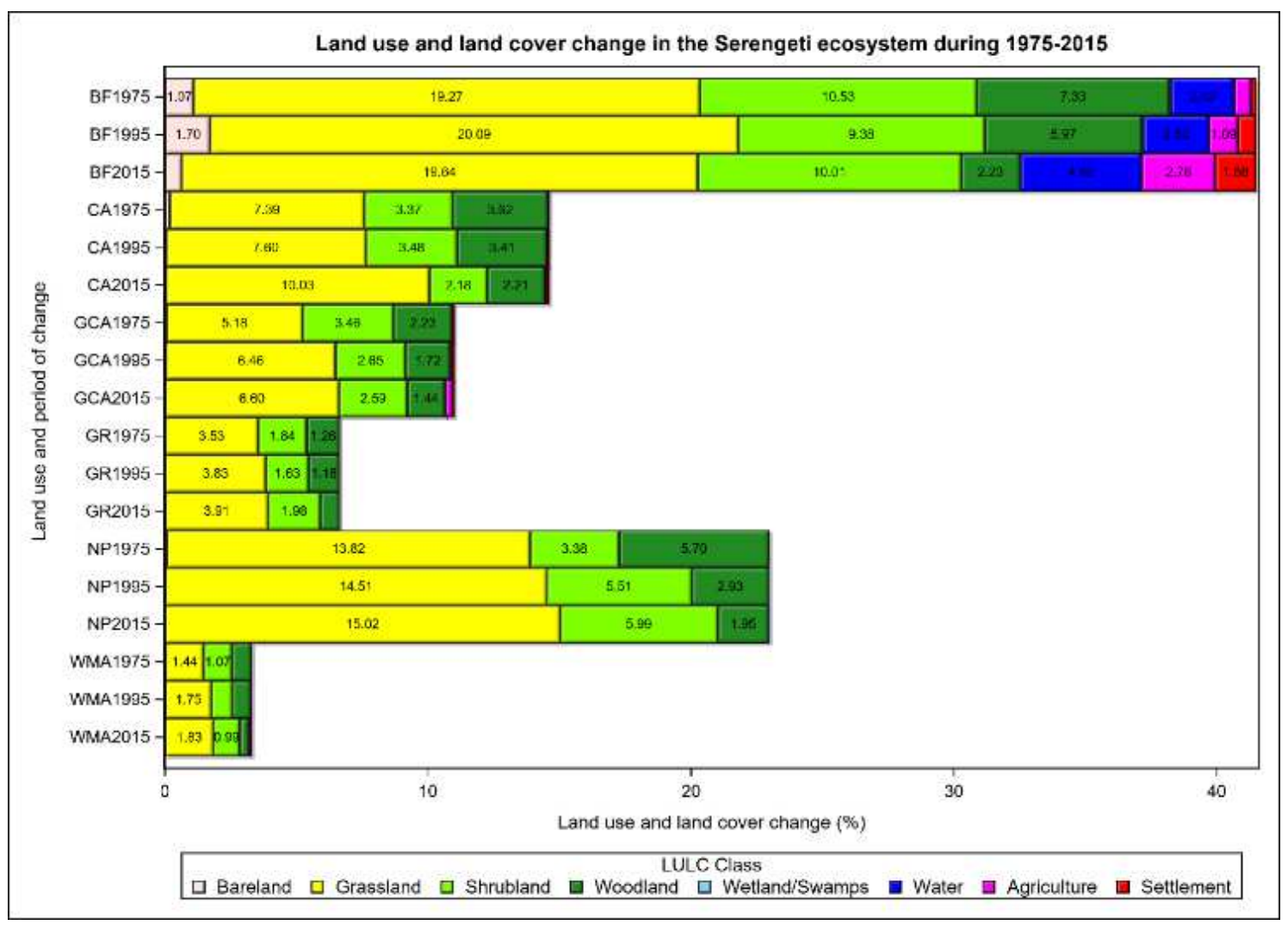

Figure 7. LULC change (\%) in different protected area categories in the GSE and surrounding buffer zone during 1975-2015. 


\subsection{LULC Cover Change (1975-2015)}

Between 1975 and 1995, woodland and shrubland coverages had the largest net declines in the ecosystem and its buffer area. Wetland/swamps coverages also declined. But grassland coverage expanded the most followed by settlements, agriculture and bareland (Figure 8). During the 1995-2015 period, the coverages of grassland, shrubland, settlement, bareland and wetland/swamps increased but those of woodland and bareland declined (Figure 8).

Woodland declined drastically and had the highest annual rate of change during 1975-2015. Bareland and wetland/swamps coverages also contracted during the 41-year study period (Figure 8). But coverages of grassland, shrubland, water, agriculture and settlements all expanded during 1975-2015 (Figure 8).

Grassland increased significantly in the buffer area and in all the protected areas except in the SNP where shrubland was more dominant than grassland during 1975-1995 (Figure 9). Bareland, water, agriculture and settlement increased notably in the buffer area (Figure 9). In contrast, woodland and shrubland coverages contracted in the buffer area and in all protected areas except in the NCA and the SNP where shrubland increased during 1975-1995 (Figure 9). Loss in woodland cover was more noticeable in the national park and the buffer area whereas the loss in shrubland cover was most marked in the buffer area and GCA (Figure 9).

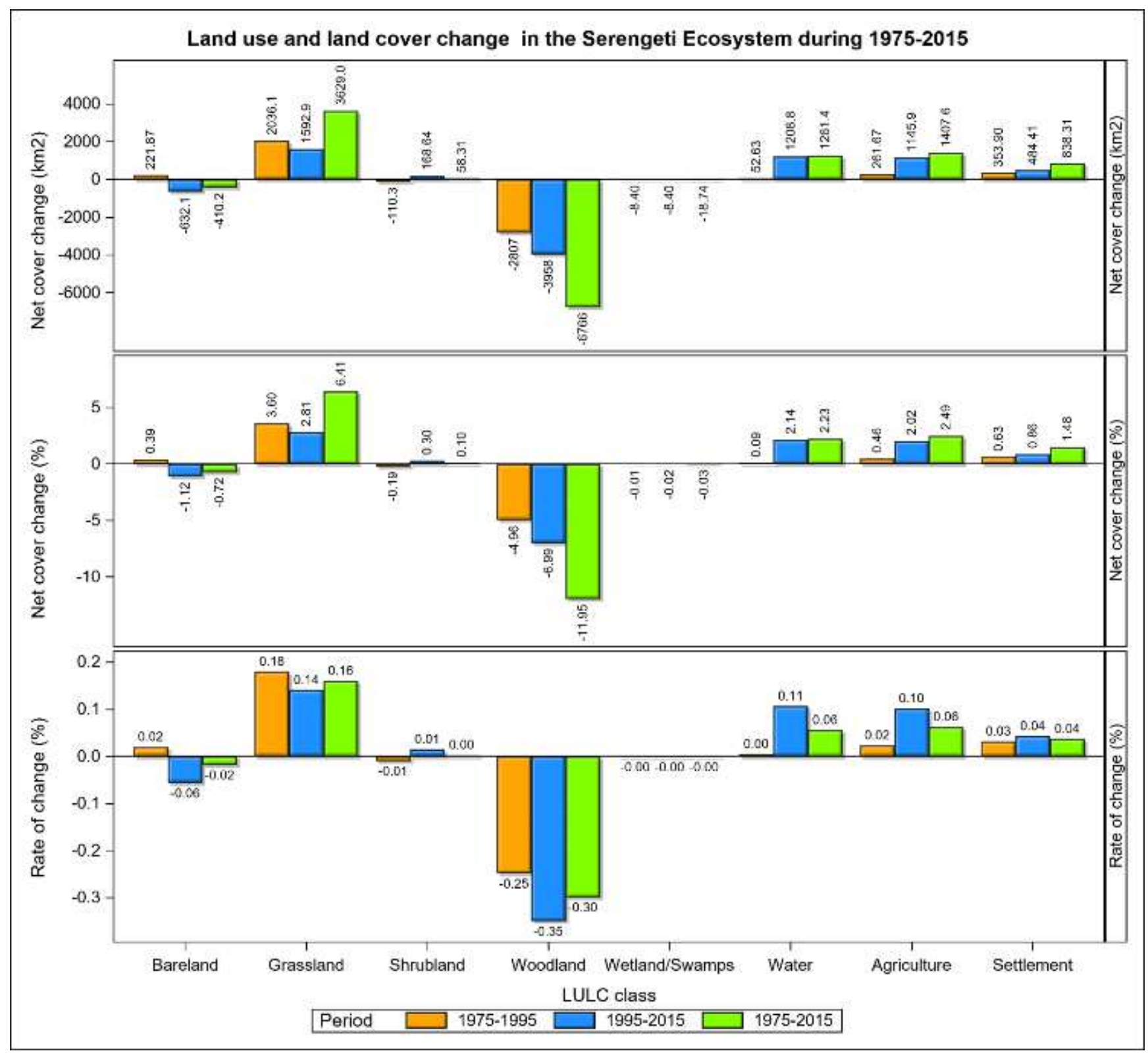

Figure 8. Net absolute $\left(\mathrm{km}^{2}\right)$ and percentage LULC changes and rate of change (\%) in the GSE and surrounding buffer area during 1975-2015. 


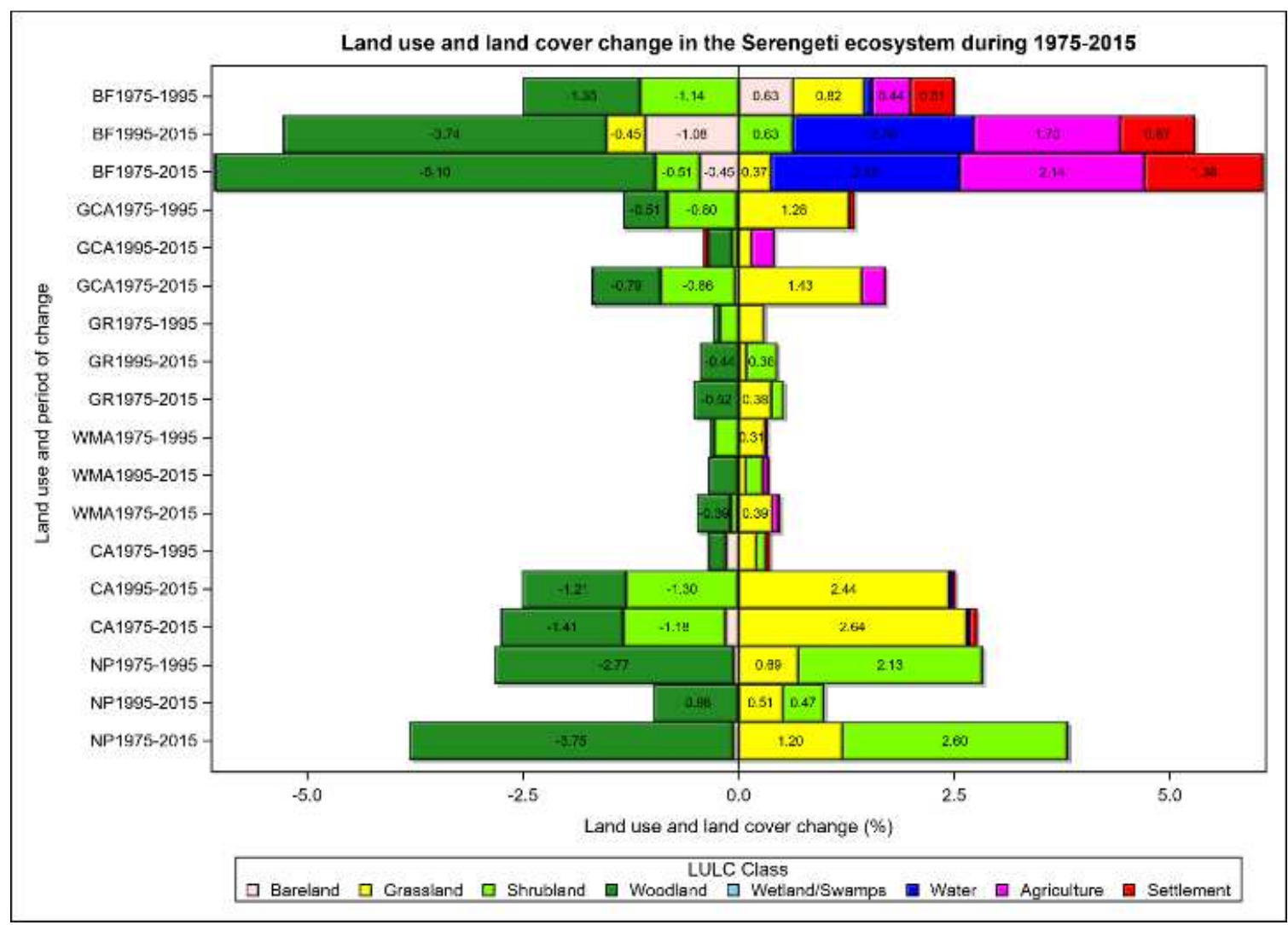

Figure 9. LULC change (\%) in each protected area category in the GSE and surrounding buffer zone during 1975-2015.

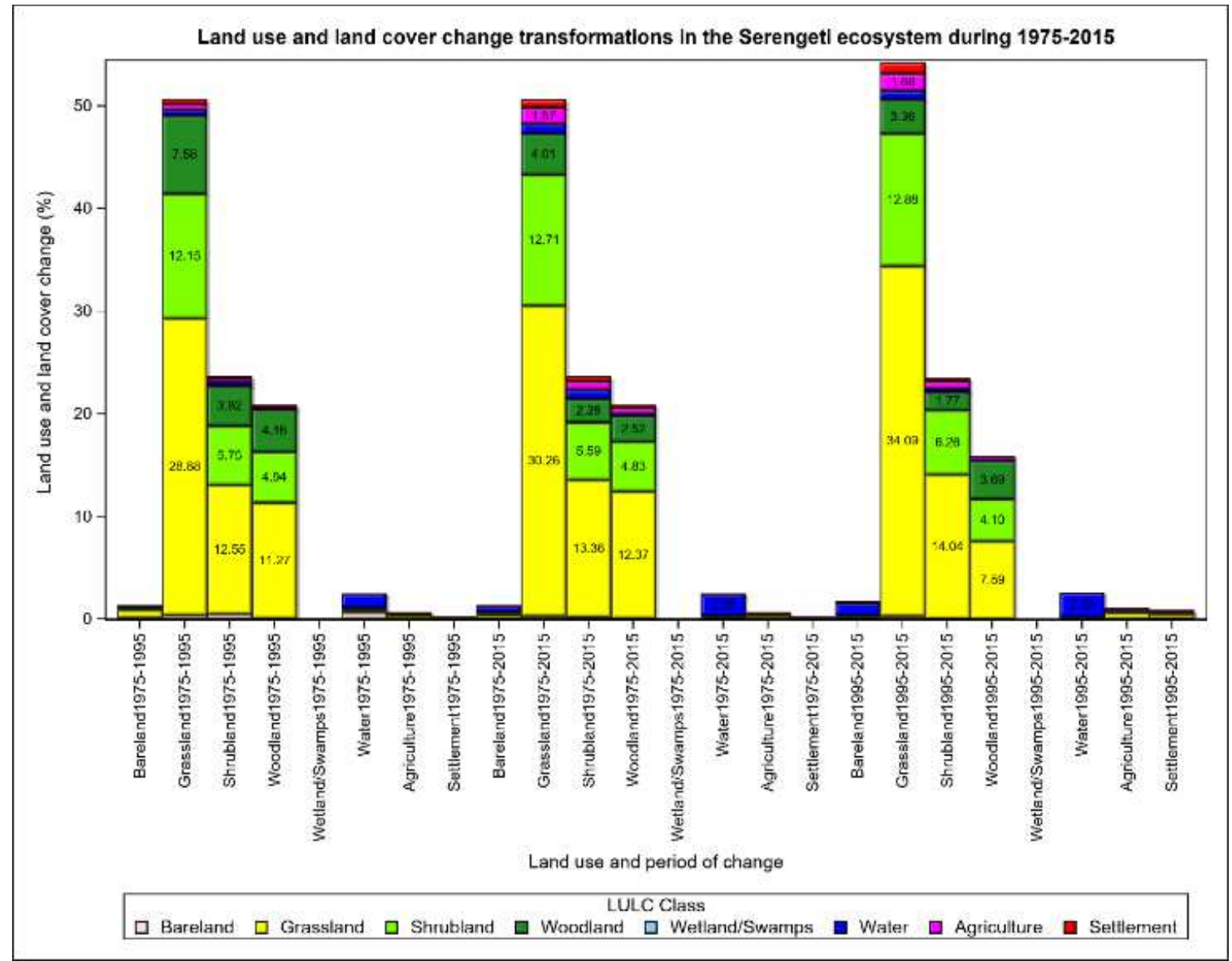

Figure 10. Transformations between LULC classes in the GSE and surrounding buffer zone during 1975-2015. 


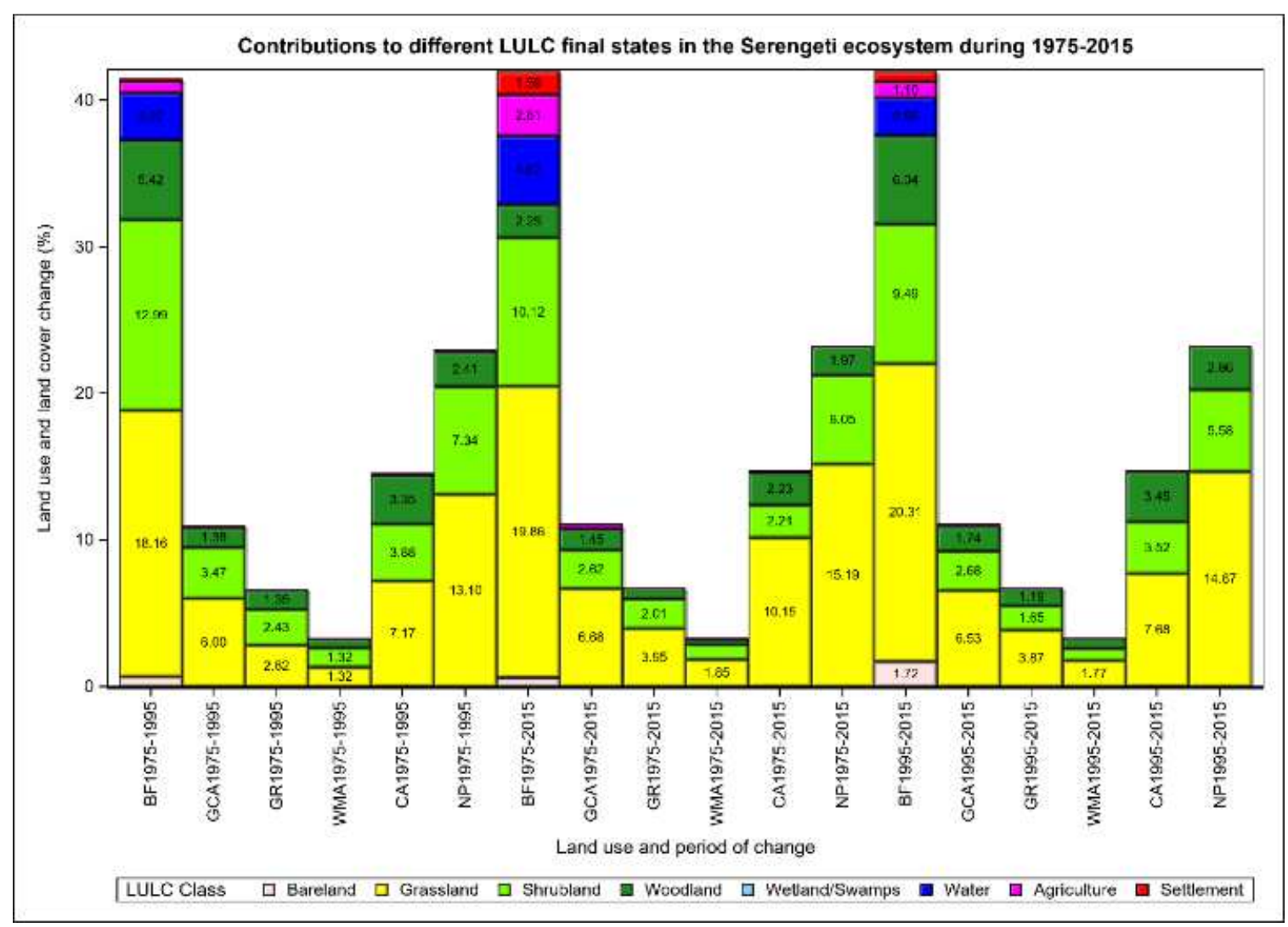

Figure 11. Contributions from different conservation categories to LULC final states during 1975-1995, 1995-2015 and 1995-2015.

During 1995-2015, woodland and bareland coverages declined the most, particularly in the buffer area, NCA and the SNP. However, shrubland cover declined mainly in the NCA but bareland cover contracted significantly in the buffer area (Figure 9).

Overall, during the entire period of assessment (1975-2015), decrease was more prominent for woodland followed by shrubland. The greatest loss of woodland occurred in the buffer area and national park. Shrubland increased in the NP but declined in the buffer area and GRs (Figure 9).

\subsection{LULC Cover Change Trajectories (1975-2015)}

During the 1975-1995 period, substantial woodland was converted to grassland and shrubland. Shrubland to grassland and woodland. Likewise, other cover types, mainly grassland were also converted to woodland and shrubland (Figure 10). The conversions of woodland, shrubland and grassland to other cover types occurred mainly in the buffer area, NCA and the NP (Figure 11). In the GCA, grassland registered the greatest conversion to other land cover types. Nevertheless, grassland, shrubland and woodland cover classes were the most persistent whereas swamps and settlement the least persistent cover classes (Figure 10).

During 1995-2015, shrubland and grassland underwent the greatest conversion to other LULC types but little woodland was converted to other types. Much of the shrubland was converted to grassland while some grassland became shrubland. Furthermore, substantial woodland cover was transformed to shrubland and grassland (Figure 10). The largest conversions of these LULC classes occurred mainly in the buffer area, SNP and NCA (Figure 11). Despite the various conversions, grassland was the most persistent cover type followed by shrubland (Figure 10).

Across the 1975-2015, the greatest transformations occurred in grasslands followed by woodlands and shrublands. Much of the grassland was converted to shrubland while considerable woodland was transformed to grassland and shrubland. Notably, most of the remaining LULC classes showed little transformations below 2\% (Figure 10). The greatest transformations of grassland and woodland were recorded for the buffer area, SNP and NCA. In addition, much of the shrubland transformations occurred in the GCA and GRs (Figure 11). Shrubland was the second most persistent cover class during the 1975-2015 period (Figure 10).

\section{Discussion}

\subsection{LULC Cover Types}

Throughout the 41 years of assessment from 1975-2015, grassland, shrubland and woodland had the highest proportions across the entire ecosystem and buffer area. The high coverages of these land cover types in the protected areas, especially in the SNP, NCA, GRs and LGCA, can be attributed mainly to their savanna characteristics and geological formation [13, 61-63]. The volcanic hard pans extending from the NCA westwards through the SNP favor grasslands, with some areas towards the west supporting grasslands interspersed with shrublands and woodlands. In the buffer area, 
the observed LULC cover changes can be attributed to anthropogenic activities, primarily agriculture, human settlement, fire and livestock grazing [64].

\subsection{LULC Cover Change}

Across the ecosystem and its surrounding buffer area, settlements, agriculture, grassland and water increased throughout 1975-2015 at the expense of woodland cover. Bareland declined during the 1975-1995 but increased during the 1995-2015. During the 1975-2015 period, grassland increased in all the protected areas unlike shrubland which increased in the NP and GRs during 1975-2015. In contrast, shrubland contracted in the GCA, where livestock grazing and agriculture are practiced, and in the NCA where pastoralism is pursued along with wildlife conservation. The expansion of grassland and shrubland cover in the Serengeti is likely the outcome of conversions from other cover types, particularly woodlands; herbivory (grazing and browsing) and fire [65, 66]. The increase in bareland coverage was coincident with human population growth and the associated expansion of agriculture and settlements, development of infrastructure and intense livestock grazing $[8,6]$.

The expansion in agriculture and settlements can be linked to human population growth and consequently increased demand for more food and income in rural Tanzania. Agriculture is the economic mainstay of the rural populations and a key source of national revenue and foreign exchange in Tanzania. The increase in settlements during the 1975-2015 was contemporaneous with increased cultivation and bareland and human population size inside the buffer area [12]. The expansion in settlement and agriculture in the ecosystem and the buffer area can be linked not only to human population growth but also to the 1974 villagization policy which involved forceful resettlement of people in nucleated villages and the policy encouraged people to cultivate the land in order to ensure to ensure food security and income for families [67, 68]. The expansion of cultivation between 1995 and 2015 was also partly driven by liberalization policies, such as the Promotion of Investment Policy of 1992 that advocated for expansion of agriculture, and consequently clearing of natural vegetation [67]. These policies also encouraged livelihood diversification, for example, from pure pastoralism to agro-pastoralism among the Maasai of LGCA and NCA in northern Tanzania [69]. However, agriculture has since then been banned to allow habitat recovery in the NCA [6]. Furthermore, socio-economic opportunities from tourism activities, livestock grazing and agriculture attracted people to the lands adjacent to the protected areas [70-73] and accentuated LULC changes. The activities aggravate the vulnerability, degradation and loss of wildlife habitats [74], adversely affecting biodiversity conservation [12]. Similarly, tourism opportunities and land suitability accelerated agricultural expansion in the adjoining Kenya's Narok County [75].

The increase in settlements around the protected areas in the Serengeti ecosystem is similar to patterns observed elsewhere [76-79], particularly in the pastoral ranches adjacent to the Masai Mara National Reserve [64] and in the Athi-Kaputiei
Plains adjoining the Kenya's Nairobi National Park in Kenya [80, 81]. Our findings reinforce and expand upon these previous studies in this [12] and other ecosystems in Tanzania, including in the Tarangire and Katavi ecosystems [12, 82, 83, 109]. Furthermore, the expansion in agriculture at the expense of natural vegetation fits in a worrying contemporary worldwide trend [74, 76-78, 84, 85-87, 88, 89].

The decline in woodland cover throughout 1975-2015 in the ecosystem and buffer area was partly due to conversion of woodlands to other cover types. Woodland vegetation is also cleared for agriculture and settlements, often resulting in shrubland and other cover types. The declining trends in woodland cover can amplify land degradation, soil erosion, salinity and loss of quality [90], leading ultimately to wildlife habitat degradation and loss. The striking decline in woodland cover in the buffer area portrays weak protection [68]. Woodland decline inside the protected areas was also concurrent with increasing elephant numbers in the ecosystem [91, 92]. Similar findings have been reported for other protected areas in Tanzania, including the Loliondo Game Controlled Area [11], Rungwa Game Reserve [93, 94], Ruaha National Park [94], Tarangire-Manyara ecosystem [95] and the Selous wildlife corridor [74]. The African elephant also often destroys woody vegetation in many African savanna ecosystems, including in Tanzania [96, 97, 91], Kenya [98, 99], Malawi [100], Zimbabwe [87], Botswana [101], as well as Ethiopia [102] and South Africa [103, 104]. Besides elephant browsing, woodland declines in the Serengeti ecosystem have been associated with frequent fires and wildebeest population growth [97]. The conversion of woodland to grassland or shrubland can create habitats favorable to grazers and some browsers but unfavorable to the elephants themselves [105, 106] and to other browsers. This can reduce the diversity and abundance of woodland-dependent species [99].

The increase in water bodies was concurrent with increasing rainfall in the Mara-Serengeti ecosystem associated with the intensification of the El Niño Southern Oscillation (ENSO) [107] and the Indian Ocean Dipole [65]. The increasing availability of water can fundamentally reshape wildlife and livestock abundance, distribution and movements in the ecosystem [108]. A protracted drought spanning 1971-1975 [107] almost certainly reduced surface water availability in the ecosystem in 1975 .

The increase in wetland/swamps between 1975 and 1995 is associated with rapid land cover transformations. Thereafter (1995-2015), wetland/swamps declined as land transformation progressed. Similar declines in swamps with progressing land transformations have also been reported for the Katavi National Park in Tanzania [109].

Generally, the declines in land cover near the protected areas jeopardize conservation initiatives run in the Wildlife management Areas (IKONA and Makao WMAs) and Outreach programme or Community Conservation Services (CCS) in the SNP. The WMAs promote community involvement in conservation through benefit-sharing schemes while reducing activities which are incompatible with conservation. The community-based conservation initiatives 
are crucial to enlisting the support of local communities for conservation and enforcing land use plans adjacent to protected areas. Otherwise, protected areas may act as push-factors or economic barriers to local communities [110].

\subsection{LULC Cover Trajectories}

The LULC change trajectories highlight dynamic transformations among different cover types. The largest transformation across the ecosystem during 1975-2015 period involved the conversion of grassland mainly to shrubland and woodland in the buffer area. In contrast, within the protected areas, considerable conversion of grassland and woodland occurred in the buffer area, SNP and the NCA during the 1975-1995 period. Between 1995 and 2015, substantial areas of grassland, shrubland and woodland were transformed to other cover types in protected areas. The degree and type of land cover transformation varied across the protected areas and was most pronounced in the national park and NCA for grassland, national park and GCA for shrubland and in the NCA and national park for woodland. This partly reflects distinctions in the level of protection and anthropogenic impacts across the protected areas. Overall, large areas of grassland, woodland and shrubland were converted in the Game Controlled Area, Wildlife Management Areas and Game Reserves with lower protection status.

The remarkable transformations of LULC in the ecosystem and buffer area were mainly associated with expansion of settlements resulting from human population growth. Human activities have transformed significant natural vegetation (including woodland) in the ecosystem into agricultural land and grasslands in the ecosystem [12, 111, 112]. Vegetation clearing for cultivation and settlement transforms woodland into grassland, shrubland and other cover types [113]. The conversion of grassland to agriculture is a widespread phenomenon in the SNP [112] and elsewhere, including rangelands in the United States [114]. Specifically, browsing and rainfall interactions transformed shrubland to grassland in the Maasai Mara ecosystem (1979-1998) in Kenya [98, 115]. Transformation of woodland to grassland is also marked in the Maasai Steppe in the Tarangire-Manyara ecosystem in northern Tanzania [22, 109, 116].

In addition, the transformations in the ecosystem and buffer area are partly due to fires. Fire partly drives woodland conversion to savannah and grassland not only in the Serengeti [117] but also in Kagoma Forest Reserve [118] in Tanzania and in South Africa $[117,119,120]$, and to shrubland in South Africa [121]. Herbivory and its interaction with rainfall can also transform woodland to grassland and other cover types [121, 119, 122]. For example, browsing-rainfall interactions transformed shrubland to grassland in the Maasai Mara in Kenya [98, 115]. Furthermore, elephant browsing transformed woodland to grassland in Kruger National Park, South Africa [123]. Browsing by impala (Aepyceros melampus) and other medium-sized browsers was responsible for retarded woodland growth in the SNP [124]. Consequently, increase in numbers of browsers such as impala in the SNP [92] might accelerate woodland loss. Browsing has also caused woodland conversion to grassland in Lake Manyara National
Park in Tanzania [95] and in Chobe National Park in Botswana [125].

\section{Conclusions and Recommendations}

This is the most comprehensive study of its kind for the Serengeti ecosystem and its surrounding buffer area. During the 41-year study period, LULC were classified into eight types (bareland, agriculture, settlement, water, grassland, shrubland, woodland and wetlands/swamps). Grassland, shrubland and woodland cover dominated the ecosystem and the buffer area throughout 1975-2015 period. The underlying local geomorphic template partly explains the dominant vegetation cover types, particularly in the SNP, NCA, GRs and in the LGCA.

The ecosystem and its buffer area experienced substantial LULC changes between 1975 and 2015. Shrubland and grassland cover increased during the 1975-1995 period but slightly during the $1995-2015$ period. The expansion of shrubland cover in the protected areas, especially in the NCA, was partly due to strong government interventions, including banning agriculture in the area in 2009. When Maasai pastoralists move from one place to another, their abandoned settlements and livestock corrals ("bomas") are typically invaded by shrublands. Bareland, agriculture and settlement increased throughout the assessment period (1975-2015). Most changes in bareland and agriculture occurred in the buffer area whereas settlements expanded in the buffer, WMAs and the Ngorongoro Conservation Area.

The contractions in LULC types mainly involved transformation from one type to another. Thus, there was substantial conversion of woodland to grassland and shrubland and from grassland to shrubland. The marked conversions were largely caused by the growing demand for more food and other agricultural products to cater for the growing human population and respond to policies that emphasized expansion of agriculture. Human population growth in rural Tanzania is associated with increasing demand for land to cater for agriculture, settlements and livestock grazing in rural Tanzania. The villagization policy of 1974 also played a significant role in land cover change during 1975-1995. Similarly, liberalization policies, such as the Promotion of Investment Policy of 1992 and policies that emphasized expansion of agriculture, and thus vegetation clearing for farms during 1995-2015. As a result, increasing human population size, settlements, farms and other socio-economic activities drive the demand for more land and hence land cover transformation. On the other hand, fire, inside and outside the ecosystem, is another factor accelerating woodland loss to savannah and grassland. The LULC changes have important impacts on wildlife habitats and biodiversity conservation. Generally, more land cover conversions occurred in buffer areas and protected areas with low protection status, notably the Game Controlled Areas and Wildlife Management Areas.

Land cover and land use mapping and change detection are essential for effective ecological monitoring of changes, 
enhancing timely and adaptive conservation interventions. Conservation spatial planning and effective implementation of the plans are also crucial. For example, community-based conservation initiatives, such as establishment of Wildlife Management Areas, Forest Reserves (Village forest reserves, community forest reserves and private forest reserves) and land use planning, and rangeland management) should be encouraged in the buffer area to regulate unsustainable resource extraction, which adversely impacts conservation and human wellbeing. The Wildlife Conservation Act No. 5 of 2009 and other related pieces of legislation (e.g., land, forest, and water) should be effectively implemented. Environmental and conservation policies should also be effectively implemented to minimize vegetation loss in the ecosystem and its buffer area. The declining vegetation cover in the buffer area should be ameliorated by planting more indigenous tree species that can also provide fuel wood, building poles and timber and relieve pressure on natural vegetation in the buffer and protected areas.

Generally, upgrading the protection status of conservation areas improves their conservation effectiveness in the Serengeti ecosystem. The substantial loss of land cover in areas of low protection status signifies the need to strengthen conservation in such areas and their buffer zones. In addition, the recorded declining trends of the LULC types call for policies, conservation and management actions that are able to control fires, regulate land use and tree felling, promote replanting trees and effectively manage elephant-tree interactions at high elephant densities. Equally important is the formulation and effective implementation of sound policies and far-sighted spatial land use plans to safeguard the future integrity of such iconic ecosystems as the Serengeti and human wellbeing in their surrounding buffer zones.

\section{Author Contributions}

$\mathrm{HK}, \mathrm{EN}, \mathrm{MS}$ and JK conceptualized and designed the research, HK collected the data, HK, EN, MS and JO and analyzed the data, and drafted the manuscript, MS, EN and JK supervised the research work, EN, MS, JO, JK, LM, BJ, BG, and $\mathrm{FV}$ reviewed and edited the manuscript for critical intellectual content.

\section{Funding}

This research work is a part of the $\mathrm{Ph}$. D study of HKK and was funded by the European Union's Horizon 2020 research and innovation grant number 641918 through the AFRICANBIOSERVICES PROJECT and by the FRIEDKIN CONSERVATION FUND (FCF). JOO was also supported by a grant from the German National Research Foundation (DFG; Grant \# 257734638).

\section{Acknowledgements}

We thank the Tanzanian Wildlife Research Institute (TAWIRI) for granting study leave and permission to HKK to conduct the research work, Tanzania National Park (TANAPA), Ngorongoro Conservation Area (NCAA), Tanzania Wildlife Management Authority (TAWA) and Wildlife Management Area Authorities (WMAs) for granting access to their areas of jurisdiction for data collection. We sincerely thank Ned Horning of the American Museum of Natural History, Centre for Biodiversity and Conservation, for guidance on using his R coded Random Forest Script. We also thank Eivin Roskaft (NTNU), Robert Fyumagwa, Janemary Ntalwila, and Machoke Mwita (TAWIRI) and Nsajigwa Mbije (SUA) for their support.

\section{References}

[1] Phukan, P., Thakuriah, G., and Saikia, R., Land use land cover change detection using remote sensing and GIS techniques-A case study of Golaghat district of Assam, India. International Research Journal of Earth Sciences, 2013. 1 (1): 11-15.

[2] Nduati, E. W., Mundia, C. N., and Ngigi, M. M., Effects of vegetation change and land use/land cover change on land surface temperature in the mara ecosystem. International Journal of Science and Research 2013. 2: 22-28.

[3] Sala, O. E., Chapin, F. S., Armesto, J. J., Berlow, E., Bloomfield, J., Dirzo, R., Huber-Sanwald, E., Huenneke, L. F., Jackson, R. B., and Kinzig, A., Global biodiversity scenarios for the year 2100. Science, 2000. 287 (5459): 1770-1774.

[4] Hamilton, C. M., Martinuzzi, S., Plantinga, A. J., Radeloff, V. C., Lewis, D. J., Thogmartin, W. E., Heglund, P. J., and Pidgeon, A. M., Current and future land use around a nationwide protected area network. PLOS ONE, 2013. 8 (1): e55737.

[5] Kidane, Y., Stahlmann, R., and Beierkuhnlein, C., Vegetation dynamics, and land use and land cover change in the Bale Mountains, Ethiopia. Environmental monitoring and assessment, 2012. 184 (12): 7473-7489.

[6] Veldhuis, M. P., Ritchie, M. E., Ogutu, J. O., Morrison, T. A., Beale, C. M., Estes, A. B., Mwakilema, W., Ojwang, G. O., Parr, C. L., Probert, J., Wargute, P. W., Hopcraft, J. G. C., and Olff, H., Cross-boundary human impacts compromise the Serengeti-Mara ecosystem. Science, 2019. 363 (6434): 1424-1428.

[7] Sinclair, A. R. E. and Arcese, P., Serengeti II: dynamics, management, and conservation of an ecosystem. Vol. 2. 1995: University of Chicago Press.

[8] Kideghesho, J. R., Nyahongo, J. W., Hassan, S. N., Tarimo, T. C., and Mbije, N. E., Factors and ecological impacts of wildlife habitat destruction in the Serengeti ecosystem in northern Tanzania. African Journal of Environmental Assessment and Management, 2006. 11: 17-32.

[9] Campbell, K. and Borner, M., Population trends and distribution of Serengeti herbivores: implications for management. Serengeti II: Dynamics, management, and conservation of an ecosystem, 1995: 117-145.

[10] Kija, H. K., Ogutu, J. O., Mangewa, L. J., Bukombe, J., Verones, F., Graae, B. J, Kideghesho, J. R., Said, M. Y., and Nzunda, E. F., Spatio-Temporal Changes in Wildlife Habitat Quality in the Greater Serengeti Ecosystem. Sustainability, 2020. 12 (6): 1-18. 
[11] Mayunga, S. D., Monitoring of Land Use/Cover Change Using Remote Sensing and GIS techniques: A case study of Loliondo Game Controlled Area, Tanzania. Trends Journal of Sciences Research, 2018.3 (1): 18-32.

[12] Estes, A. B., Kuemmerle, T., Kushnir, H., Radeloff, V. C., and Shugart, H. H., Land-cover change and human population trends in the greater Serengeti ecosystem from 1984-2003. Biological Conservation, 2012. 147 (1): 255-263.

[13] Reed, D. N., Anderson, T. M., Dempewolf, J., Metzger, K., and Serneels, S., The spatial distribution of vegetation types in the Serengeti ecosystem: the influence of rainfall and topographic relief on vegetation patch characteristics. Journal of Biogeography, 2009. 36 (4): 770-782.

[14] Byrom, A. E., Nkwabi, A. J., Metzger, K., Mduma, S. A., Forrester, G. J., Ruscoe, W. A., Reed, D. N., Bukombe, J., Mchetto, J., and Sinclair, A., Anthropogenic stressors influence small mammal communities in tropical East African savanna at multiple spatial scales. Wildlife Research, 2015.42 (2): 119-131.

[15] Serneels, S., Said, M., and Lambin, E., Land cover changes around a major east African wildlife reserve: the Mara Ecosystem (Kenya). International Journal of Remote Sensing, 2001. 22 (17): 3397-3420

[16] Sinclair, A., Hopcraft, J. G. C., Olff, H., Mduma, S. A., Galvin, K. A., and Sharam, G. J., Historical and future changes to the Serengeti ecosystem. Serengeti III: Human impacts on ecosystem dynamics, 2008: 7-46.

[17] Sinclair, A., Packer, C., Mduma, S. A., and Fryxell, J. M., Serengeti III: human impacts on ecosystem dynamics. 2009: University of Chicago Press.

[18] Estes, A. B., Using remote sensing to uncover the drivers of land-cover change and elephant habitat use in the Serengeti ecosystem. Unpublished Thesis for Award of PhD Degree at University of Virginia, United States of America. 2012. pp. 152.

[19] Fryxell, J. M., Wilmshurst, J. F., and Sinclair, A. R., Predictive models of movement by Serengeti grazers. Ecology, 2004. 85 (9): 2429-2435.

[20] Gottschalk, T. K., Ekschmitt, K., and Bairlein, F., A GIS-based model of Serengeti grassland bird species. Ostrich-Journal of African Ornithology, 2007. 78 (2): 259-263.

[21] Kikula, I. S., Policy Implications on Environment. The Case of Villagization in Tanzania. 1997, DUP (1996) LTD, University of Dar es Salaam, Tanzania.

[22] Msoffe, F. U., Said, M. Y., Ogutu, J. O., Kifugo, S. C., De Leeuw, J., Van Gardingen, P., and Reid, R., Spatial correlates of land-use changes in the Maasai-Steppe of Tanzania: Implications for conservation and environmental planning. International Journal of Biodiversity and Conservation, 2011.3 (7): $280-290$.

[23] Leyaro, V. and Morrissey, O., Expanding agricultural production in Tanzania. 2013.

[24] Mtui, D. T., Evaluating landscape and wildlife changes over time in Tanzania's protected areas. 2014, [Honolulu]:[University of Hawaii at Manoa],[December 2014].

[25] Norton-Griffiths, M., Herlocker, D., and Pennycuick, L., The patterns of rainfall in the Serengeti ecosystem, Tanzania. African Journal of Ecology, 1975. 13 (3-4): 347-374.
[26] Ogutu, J. O., Piepho, H. P., Dublin, H. T., Bhola, N., and Reid, R. S., Rainfall influences on ungulate population abundance in the Mara-Serengeti ecosystem. J Anim Ecol, 2008. 77 (4): 814-29.

[27] Herlocker, D. J., Structure, composition, and environment of some woodland vegetation types of the Serengeti National Park, Tanzania. 1976: Herlocker.

[28] Gottschalk, T. K., Ekschmitt, K., and Bairlein, F., Relationships between vegetation and bird community composition in grasslands of the Serengeti. African journal of ecology, 2007. 45 (4): 557-565.

[29] Thirgood, S., Mosser, A., Tham, S., Hopcraft, G., Mwangomo, E., Mlengeya, T., Kilewo, M., Fryxell, J., Sinclair, A. R. E., and Borner, M., Can parks protect migratory ungulates? The case of the Serengeti wildebeest. Animal Conservation, 2004. 7 (02): 113-120.

[30] Chander, G., Markham, B. L., and Helder, D. L., Summary of current radiometric calibration coefficients for Landsat MSS, TM, ETM+, and EO-1 ALI sensors. Remote sensing of environment, 2009. 113 (5): 893-903.

[31] Pons, X., Pesquer, L., Cristóbal, J., and González-Guerrero, O., Automatic and improved radiometric correction of Landsat imagery using reference values from MODIS surface reflectance images. International Journal of Applied Earth Observation and Geoinformation, 2014. 33: 243-254.

[32] Young, N. E., Anderson, R. S., Chignell, S. M., Vorster, A. G., Lawrence, R., and Evangelista, P. H., A survival guide to Landsat preprocessing. Ecology, 2017. 98 (4): 920-932.

[33] Chavez, P. S., Image-based atmospheric corrections-revisited and improved. Photogrammetric engineering and remote sensing, 1996. 62 (9): 1025-1035.

[34] Franklin, S. E. and Giles, P. T., Radiometric processing of aerial and satellite remote-sensing imagery. Computers \& Geosciences, 1995. 21 (3): 413-423.

[35] Amro, I., Mateos, J., Vega, M., Molina, R., and Katsaggelos, A. K., A survey of classical methods and new trends in pansharpening of multispectral images. EURASIP Journal on Advances in Signal Processing, 2011. 2011 (1): 79.

[36] Pons, X. and Solé-Sugrañes, L., A simple radiometric correction model to improve automatic mapping of vegetation from multispectral satellite data. Remote sensing of Environment, 1994. 48 (2): 191-204.

[37] Riaño, D., Chuvieco, E., Salas, J., and Aguado, I., Assessment of different topographic corrections in Landsat-TM data for mapping vegetation types (2003). IEEE Transactions on geoscience and remote sensing, 2003. 41 (5): 1056-1061.

[38] Shepherd, J. and Dymond, J., Correcting satellite imagery for the variance of reflectance and illumination with topography. International Journal of Remote Sensing, 2003. 24 (17): 3503-3514.

[39] Jensen, J. R., Thematic information extraction: Image classification. Introductory Digital Image Processing: A Remote Sensing Perspective, 1996: 197-256.

[40] Ekstrand, S., Landsat TM-based forest damage assessment: correction for topographic effects. Photogrammetric Engineering and Remote Sensing, 1996. 62 (2): 151-162. 
[41] Gao, Y. and Zhang, W., LULC classification and topographic correction of Landsat-7 ETM+ imagery in the Yangjia River Watershed: the influence of DEM resolution. Sensors, 2009. 9 (3): 1980-1995.

[42] PCI, PCI Geomatics Software, in PCI Geomatics, Ontario. 2015: Canada.

[43] Congalton, R. G., A review of assessing the accuracy of classifications of remotely sensed data. Remote Sensing of Environment, 1991. 37 (1): 35-46.

[44] Thomlinson, J. R., Bolstad, P. V., and Cohen, W. B., Coordinating methodologies for scaling landcover classifications from site-specific to global: Steps toward validating global map products. Remote Sensing of Environment, 1999. 70 (1): 16-28.

[45] Blaschke, T., Object based image analysis for remote sensing. ISPRS journal of photogrammetry and remote sensing, 2010 65 (1): 2-16.

[46] Horning, N. Random Forests: An algorithm for image classification and generation of continuous fields data sets. in Proceedings of the International Conference on Geoinformatics for Spatial Infrastructure Development in Earth and Allied Sciences, Osaka, Japan. 2010.

[47] Cutler, D. R., Edwards, T. C., Beard, K. H., Cutler, A., Hess, K. T., Gibson, J., and Lawler, J. J., Random forests for classification in ecology. Ecology, 2007. 88 (11): 2783-2792.

[48] Frakes, R. A., Belden, R. C., Wood, B. E., and James, F. E., Landscape Analysis of Adult Florida Panther Habitat. PLOS ONE, 2015. 10 (7)

[49] Rodriguez-Galiano, V. F., Ghimire, B., Rogan, J., Chica-Olmo, M., and Rigol-Sanchez, J. P., An assessment of the effectiveness of a random forest classifier for land-cover classification. ISPRS Journal of Photogrammetry and Remote Sensing, 2012. 67: 93-104.

[50] Pangelova, B. and Rogan, J. Land cover and land use change detection and analyses in Plovdiv, Bulgaria, between 1986 and 2000. in Proceedings from Annual Conference of the American Society for Photogrammetry and Remote Sensing. 2006.

[51] Rodriguez-Galiano, V., Chica-Olmo, M., Abarca-Hernandez, F., Atkinson, P. M., and Jeganathan, C., Random Forest classification of Mediterranean land cover using multi-seasonal imagery and multi-seasonal texture. Remote Sensing of Environment, 2012. 121: 93-107.

[52] Lillesand, T., Kiefer, R., and Chipman, J., Digital image interpretation and analysis. Remote sensing and image interpretation, 2008. 6: 545-81.

[53] Lu, D., Weng, Q., Moran, E., Li, G., and Hetrick, S., Remote sensing image classification. 2011: CRC Press/Taylor and Francis: Boca Raton, FL, USA.

[54] Olofsson, P., Foody, G. M., Herold, M., Stehman, S. V., Woodcock, C. E., and Wulder, M. A., Good practices for estimating area and assessing accuracy of land change. Remote Sensing of Environment, 2014. 148: 42-57.

[55] Shalaby, A. and Tateishi, R., Remote sensing and GIS for mapping and monitoring land cover and land-use changes in the Northwestern coastal zone of Egypt. Applied Geography, 2007. 27 (1): 28-41.

[56] Foody, G. M., Status of land cover classification accuracy assessment. Remote sensing of environment, 2002. 80 (1): $185-201$.

[57] Tateishi, R., Tsend-Ayush, J., Ghar, M. A., Al-Bilbisi, H., and Okatani, T., Sampling Methods for Validation of Large Area Land Cover Mapping. Journal of The Remote Sensing Society of Japan, 2007. 27 (3): 195-204.

[58] Lillesand, T., Kiefer, R. W., and Chipman, J., Remote sensing and image interpretation. 2015: John Wiley \& Sons.

[59] Congedo, L., Semi-Automatic Classification Plugin for QGIS. Sapienza University, Rome. 2013.

[60] Tekle, K. and Hedlund, L., Land Cover Changes Between 1958 and 1986 in Kalu District, Southern Wello, Ethiopia. Mountain Research and Development, 2000. 20 (1): 42-51.

[61] McNaughton, S., Serengeti grassland ecology: the role of composite environmental factors and contingency in community organization. Ecological monographs, 1983. 53 (3): 291-320.

[62] Metzger, K. L., Sinclair, A. R., Macfarlane, A., Coughenour, M., and Ding, J., Scales of change in the Greater Serengeti ecosystem. Serengeti IV: Sustaining Biodiversity in a Coupled Human-Natural System'. (Eds ARE Sinclair, KL Metzger, JM Fryxell and SAR Mduma.) pp, 2015: 33-71.

[63] Michael Anderson, T., Metzger, K. L., and McNaughton, S. J., Multi-scale analysis of plant species richness in Serengeti grasslands. Journal of Biogeography, 2007. 34 (2): 313-323.

[64] Ogutu, J. O., Piepho, H. P., Dublin, H. T., Bhola, N., and Reid, R. S., Dynamics of Mara-Serengeti ungulates in relation to land use changes. Journal of Zoology, 2009. 278 (1): 1-14.

[65] Bartzke, G. S., Ogutu, J. O., Mukhopadhyay, S., Mtui, D., Dublin, H. T., and Piepho, H. P., Rainfall trends and variation in the Maasai Mara ecosystem and their implications for animal population and biodiversity dynamics. PLOS ONE, 2018. 13 (9): e0202814.

[66] Rutina, L. P., Moe, S. R., and Swenson, J. E., Elephant Loxodonta africana driven woodland conversion to shrubland improves dry-season browse availability for impalas Aepyceros melampus. Wildlife Biology, 2005. 11 (3): 207-213.

[67] Arndt, C., Farmer, W., Strzepek, K., and Thurlow, J., Climate change, agriculture and food security in Tanzania. 2012: The World Bank.

[68] Luoga, E. J., Witkowski, E. T. F., and Balkwill, K., Land Cover and Use Changes in Relation to the Institutional Framework and Tenure of Land and Resources in Eastern Tanzania Miombo Woodlands. Environment, Development and Sustainability, 2005. 7 (1): 71-93.

[69] McCabe, J. T., Leslie, P. W., and DeLuca, L., Adopting cultivation to remain pastoralists: the diversification of Maasai livelihoods in northern Tanzania. Human ecology, 2010. 38 (3): 321-334.

[70] Homewood, K., Kristjanson, P., and Trench, P. C., Changing Land Use, Livelihoods and Wildlife Conservation in Maasailand. 2009. 5: 1-42.

[71] Homewood, K., Lambin, E. F., Coast, E., Kariuki, A., Kikula, I., Kivelia, J., Said, M., Serneels, S., and Thompson, M., Long-term changes in Serengeti-Mara wildebeest and land cover: pastoralism, population, or policies? Proc Natl Acad Sci USA, 2001.98 (22): 12544-9. 
[72] Oglethorpe, J., Ericson, J., Bilsborrow, R. E., and Edmond, J., People on the move: Reducing the impacts of human migration on biodiversity. World Wildlife Fund and Conservation International Foundation, Washington, DC, 2007.

[73] Scholte, P. and de Groot, W. T., From Debaste to Insight: There Models of Immigration to Protected Areas. Conservation Biology, 2010. 24 (2): 630-632.

[74] Ntongani, W. A., Munishi, P. K., and Mbilinyi, B. P., Land use changes and conservation threats in the eastern Selous-Niassa wildlife corridor, Nachingwea, Tanzania. African journal of ecology, 2010. 48 (4): 880-887.

[75] Serneels, S. and Lambin, E. F., Proximate causes of land-use change in Narok District, Kenya: a spatial statistical model. Agriculture, Ecosystems \& Environment, 2001.85 (1): 65-81.

[76] Mugagga, F., Kakembo, V., and Buyinza, M., Land use changes on the slopes of Mount Elgon and the implications for the occurrence of landslides. Catena, 2012. 90: 39-46.

[77] Mussa, M., Teka, H., and Mesfin, Y., Land use/cover change analysis and local community perception towards land cover change in the lowland of Bale rangelands, Southeast Ethiopia. International Journal of Biodiversity and Conservation, 2017. 9 (12): 363-372.

[78] Odada, E. O., Ochola, W. O., and Olago, D. O., Drivers of ecosystem change and their impacts on human well-being in Lake Victoria basin. African Journal of Ecology, 2009. 47: 46-54.

[79] Warra, H., Mohammed, A., and D Nicolau, M., Spatio-temporal Impact of Socio-economic practices on land use/cover in the Kasso catchment, Bale Mountains, Ethiopia. Analele stiintifice ale Universitatii" Alexandru Ioan Cuza" din Iasi-seria Geografie, 2013. 59 (1): 95-120.

[80] Ogutu, J., Owen-Smith, N., Piepho, H.-P., Said, M. Y., Kifugo, S. C., Reid, R. S., Gichohi, H., Kahumbu, P., and Andanje, S., Changing wildlife populations in Nairobi national park and adjoining Athi-Kaputiei plains: Collapse of the migratory Wildebeest. The Open Conservation Biology Journal, 2013. 7 (1).

[81] Said, M. Y., Ogutu, J. O., Kifugo, S. C., Makui, O., Reid, R. S., and de Leeuw, J., Effects of extreme land fragmentation on wildlife and livestock population abundance and distribution. Journal for Nature Conservation, 2016. 34: 151-164.

[82] Msoffe, F. U., Kifugo, S. C., Said, M. Y., Neselle, M. O., Van Gardingen, P., Reid, R. S., Ogutu, J. O., Herero, M., and De Leeuw, J., Drivers and impacts of land-use change in the Maasai Steppe of northern Tanzania: an ecological, social and political analysis. Journal of Land Use Science, 2011. 6 (4): 261-281.

[83] Njamasi, Y. R., The impact of human activities on wildlife in Kwakuchinja migratory corridor-Tarangire/Manyara ecosystem (TME), Northern Tanzania. 2015, Department of Wildlife Management and Conservation, Sokoine University of Agriculture, Tanzania.

[84] Ariti, A. T., van Vliet, J., and Verburg, P. H., Land-use and land-cover changes in the Central Rift Valley of Ethiopia: Assessment of perception and adaptation of stakeholders. Applied Geography, 2015. 65: 28-37.

[85] Fisseha, G., Gebrekidan, H., Kibret, K., Yitaferu, B., and Bedadi, B., Analysis of land use/land cover changes in the
Debre-Mewi watershed at the upper catchment of the Blue Nile Basin, North West Ethiopia. J. Biodivers. Environ. Sci, 2011. 1 (6): 184-198.

[86] Forkuor, G. and Cofie, O., Dynamics of land-use and land-cover change in Freetown, Sierra Leone and its effects on urban and peri-urban agriculture a remote sensing approach. International Journal of Remote Sensing, 2011. 32 (4): $1017-1037$

[87] Kamusoko, C. and Aniya, M., Land use/cover change and landscape fragmentation analysis in the Bindura District, Zimbabwe. Land degradation \& development, 2007. 18 (2): 221-233.

[88] Mwavu, E. and Witkowski, E., Land-use and cover changes (1988-2002) around Budongo forest reserve, NW Uganda: Implications for forest and woodland sustainability. Land degradation \& development, 2008. 19 (6): 606-622.

[89] Zoungrana, B. J., Conrad, C., Amekudzi, L. K., Thiel, M., Da, E. D., Forkuor, G., and Löw, F., Multi-temporal landsat images and ancillary data for land use/cover change (LULCC) detection in the Southwest of Burkina Faso, West Africa. Remote Sensing, 2015.7 (9): 12076-12102.

[90] Miheretu, B. A. and Yimer, A. A., Land use/land cover changes and their environmental implications in the Gelana sub-watershed of Northern highlands of Ethiopia. Environmental Systems Research, 2017. 6 (1).

[91] Ruess, R. and Halter, F., The impact of large herbivores on the Seronera woodlands, Serengeti National Park, Tanzania. African Journal of Ecology, 1990. 28 (4): 259-275.

[92] TAWIRI, Aerial Survey in the Serengeti ecosystem (Unpublished report). Tanzania Wildlife Research Institute (TAWIRI), Arusha, Tanzania. 2018.

[93] Barnes, R., Effects of elephant browsing on woodlands in a Tanzanian National Park: measurements, models and management. Journal of Applied Ecology, 1983: 521-539.

[94] Barnes, R., Woodland changes in Ruaha National park (Tanzania) between 1976 and 1982. African Journal of Ecology, 1985. 23 (4): 215-221.

[95] Prins, H. H. and van der Jeugd, H. P., Herbivore population crashes and woodland structure in East Africa. Journal of Ecology, 1993: 305-314.

[96] Lamprey, H., Glover, P. E., Turner, M. I., and Bell, R. H., Invasion of the Serengeti National Park by elephants. African Journal of Ecology, 1967. 5 (1): 151-166.

[97] Norton-Griffiths, M., The influence of grazing, browsing, and fire on the vegetation dynamics of the Serengeti. Serengeti: dynamics of an ecosystem. University of Chicago Press, Chicago, 1979: 310-352.

[98] Dublin, H. T., Vegetation dynamics in the Serengeti-Mara ecosystem: the role of elephants, fire, and other factors, in Serengeti II: dynamics, management, and conservation of an ecosystem. University of Chicago Press, Chicago. 1995. p. 71-90.

[99] Walpole, M. J., Nabaala, M., and Matankory, C., Status of the Mara woodlands in Kenya. African Journal of Ecology, 2004.

[100] Abbot, J. I. and Homewood, K., A history of change: causes of miombo woodland decline in a protected area in Malawi. Journal of Applied Ecology, 1999. 36 (3): 422-433. 
[101] Morrison, T. A., Holdo, R. M., and Anderson, T. M., Elephant damage, not fire or rainfall, explains mortality of overstorey trees in Serengeti. Journal of Ecology, 2016. 104 (2): 409-418.

[102] Lemessa, D., Asmelash, F., Teka, Y., Alemu, S., Didita, M., and Melesse, S., Woody Species Composition in Relation to Spatial and Environmental Gradients in Acacia-Commiphora Vegetation Ecosystem of Ethiopia.

[103] Guldemond, R. and Van Aarde, R., A meta-analysis of the impact of African elephants on savanna vegetation. The Journal of Wildlife Management, 2008. 72 (4): 892-899.

[104] Scholtz, R., Kiker, G., Smit, I., and Venter, F., Identifying drivers that influence the spatial distribution of woody vegetation in Kruger National Park, South Africa. Ecosphere, 2014. 5 (6): 1-12.

[105] Dublin, H. T., Dynamics of the Serengeti-Mara woodlands: an historical perspective. Forest \& Conservation History, 1991. 35 (4): 169-178.

[106] Dublin, H. T., Sinclair, A. R., and McGlade, J., Elephants and fire as causes of multiple stable states in the Serengeti-Mara woodlands. The Journal of Animal Ecology, 1990: 1147-1164.

[107] Ogutu, J., Piepho, H. P., Dublin, H., Bhola, N., and Reid, R., El Niño-Southern Oscillation, rainfall, temperature and Normalized Difference Vegetation Index fluctuations in the Mara-Serengeti ecosystem. African Journal of Ecology, 2008. 46 (2): 132-143.

[108] de Leeuw, J., Waweru, M. N., Okello, O. O., Maloba, M., Nguru, P., Said, M. Y., Aligula, H. M., Heitkönig, I. M., and Reid, R. S., Distribution and diversity of wildlife in northern Kenya in relation to livestock and permanent water points. Biological Conservation, 2001. 100 (3): 297-306.

[109] Mtui, D. T., Lepczyk, C. A., Chen, Q., Miura, T., and Cox, L. J., Assessing multi-decadal land-cover - land-use change in two wildlife protected areas in Tanzania using Landsat imagery. PLOS ONE, 2017. 12 (9).

[110] Joppa, L., Population change in and around protected areas. Journal of Ecological Anthropology, 2012.15 (1): 58-64.

[111] Sinclair, A. R., Mduma, S. A., and Arcese, P., Protected areas as biodiversity benchmarks for human impact: agriculture and the Serengeti avifauna. Proceedings of the Royal Society of London B: Biological Sciences, 2002. 269 (1508): 2401-2405.

[112] Soka, G. E. and Ritchie, M. E., Land-Cover legacy effects on arbuscular mycorrhizal abundance in human and wildlife dominated systems in tropical savanna. Advances in Ecology, 2016. 2016 .

[113] Campbell, B. M., The Miombo in transition: woodlands and welfare in Africa. 1996: CIFOR.
[114] Mitchell, J. E., Rangeland resource trends in the United States: A technical document supporting the 2000 USDA Forest Service RPA Assessment. 2000: US Department of Agriculture, Forest Service, Rocky Mountain Research Station.

[115] Sinclair, A. R. E. and Norton-Griffiths, M., Serengeti: dynamics of an ecosystem. 1984: University of Chicago Press.

[116] Mwalyosi, R. B., Land-use changes and resource degradation in south-west Masailand, Tanzania. Environmental Conservation, 1992.19 (2): 145-152.

[117] Holdo, R. M., Holt, R. D., and Fryxell, J. M., Grazers, browsers, and fire influence the extent and spatial pattern of tree cover in the Serengeti. Ecological Applications, 2009. 19 (1): 95-109.

[118] Nzunda, N. G., Socio-economic factors influencing land use and vegetation cover changes in and around Kagoma Forest Reserve Kagera region, Tanzania. 2011, Sokoine University of Agriculture (SUA).

[119] Sankaran, M., Ratnam, J., and Hanan, N., Woody cover in African savannas: the role of resources, fire and herbivory. Global Ecology and Biogeography, 2008. 17 (2): 236-245.

[120] Van Langevelde, F., Van De Vijver, C. A., Kumar, L., Van De Koppel, J., De Ridder, N., Van Andel, J., Skidmore, A. K., Hearne, J. W., Stroosnijder, L., and Bond, W. J., Effects of fire and herbivory on the stability of savanna ecosystems. Ecology, 2003. 84 (2): 337-350.

[121] Cumming, D. H., Fenton, M. B., Rautenbach, I. L., Taylor, R. D., Cumming, G. S., Cumming, M. S., Dunlop, J. M., Ford, A. G., Hovorka, M. D., and Johnston, D. S., Elephants, woodlands and biodiversity in southern Africa. South African Journal of Science, 1997. 93 (5): 231-236.

[122] Zyambo, P., Woodland Conversion by Elephants in Africa: The Search for Causal Factors, Processes, Mechanisms and Management Strategies. Open Journal of Ecology, 2016. 06 (02): 93-101.

[123] Van de Koppel, J. and Prins, H. H., The importance of herbivore interactions for the dynamics of African savanna woodlands: an hypothesis. Journal of Tropical Ecology, 1998. 14 (5): 565-576.

[124] Belsky, A. J., Role of small browsing mammals in preventing woodland regeneration in the Serengeti National Park, Tanzania. African Journal of Ecology, 1984. 22 (4): 271-279.

[125] Barnes, M. E., Effects of large herbivores and fire on the regeneration of Acacia erioloba woodlands in Chobe National Park, Botswana. African Journal of Ecology, 2001. 39 (4): 340-350. 